\title{
THE CATALAN LEGAL TRADITION (THE VALUE OF INTERPRETATION AND THE WEIGHT OF HISTORY)
}

\section{Dr. José María Pérez Collados}

Professor of History of Law at the University of Girona

Correspondence: josemaria.perez@udg.edu

Received:

1.9.2019

Accepted:

1.10.2019

\section{How to cite this paper}

Pérez Collados, Jose María (2019): The catalan tradition (the value of interpretation and the weight of history). Spanish Journal of Legislative Studies. (1), p1-40. DOI: https://doi.org/10.21134/ sjls.v0i1.1707 


\section{INTRODUCTION: THE LEGAL RE- LEVANCE OF AN INDETERMINATE LEGAL CONCEPT: THE CATALAN LEGAL TRADITION}

On 30 ${ }^{\text {th }}$ December 2002 the Catalan Parliament promulgated the first law of the Civil Code of Catalonia1. Its main objective, as stated in the preamble, is to 'establish the structure, the basic content and the procedural processes of the Civil Code of Catalonia'. This law also introduced the first of the six books that were to set out the Catalan Civil Code.

In this first book, which deals with the General Dispositions, there is an article, number 111-2², found under the heading 'Interpretation and Integration', which in its second paragraph states: In its application, the civil law of Catalonia must be interpreted and integrated in accordance with the general principles that inform it, taking the Catalan legal tradition into consideration.

A concept appears, that of the Catalan legal tradition, which is given an integrative and interpretative value. The idea is most novel: the legal tradition of the country, of the territory, becomes a criterion of legislative integration and interpretation. This approach most certainly has no equivalent in other civil codes: it is truly original.

Our curiosity is further aroused as we continue to read the preamble of the law and, with respect to this article, we find: 'The regulation recognises in the general principles of law their function of self-integration into the civil law of Catalonia, as a means to avoid heterointegration by applying supplementary law, and their importance as a li- mitation to a possible indiscriminate allegation of the Catalan legal tradition.'

In other words, as article 111-1 affirms, the general principles of law are considered to be a legislative source with a dual-purpose integrative function: on the one hand, they avoid heterointegration, and on the other hand, they impede 'a possible indiscriminate allegation of the $\mathrm{Ca}$ talan legal tradition'. The Catalan legal tradition, therefore, appears in the Civil Code of Catalonia accompanied by a certain mistrust, and given a value which defines but also limits it, claiming a possible 'indiscriminate allegation' which, whilst very Catalan, is still disconcerting.

This is certainly not the tenor that regulates the concept in the Legislative Decree 1/1984 of the $19^{\text {th }}$ June, which approved the Revised Text of the Compilation of Civil Law of Catalonia. Article 1-2 of this documents reads: 'when interpreting and integrating this Compilation and the rest of the regulations, the laws, customs, jurisprudence and doctrine that constitute the Catalan legal tradition will be taken into consideration in accordance with the general principles that inspire the legal system of Catalonia'.

Taking this further, Article 1 of the law of $21^{\text {st }}$ July 1960, which approved the Compilation of $\mathrm{Ci}$ vil Law of Catalonia, recognised the Catalan legal tradition as the only interpretative criteria of the Compilation, making no reference at all to general principles of the Catalan system of civil law with which the tradition should be combined when it is integrated and interpreted. It reads thus: 'In order to interpret the precepts of this Compilation, the Catalan legal tradition, which is represented

\footnotetext{
${ }^{1}$ BOE [Official State Gazette], no. 32, $6^{\text {th }}$ February 2003, pp. 4912-4918. It must be noted that the Constitutional Tribunal declared admissible, by judicial order dated $20^{\text {th }}$ May 2003, the appeal of unconstitutionality no. 2099/2003 brought against this law by the Presidency of the Government.

${ }^{2}$ The numbering system of this code is made up of two figures separated by a hyphen. The first of these has three numbers, which refer to the relevant Book, title and chapter respectively. The second figure refers to the article of the chapter in question.
} 
in the old laws, customs and doctrine from which these precepts are derived, will be taken into consideration.'

The concept Catalan legal tradition thus passes from being the sole interpretative criteria of Catalan civil law (in the Compilation of 1960) to sharing both this role and that of integration with the general principles of the Catalan legal system (Revised Text of the Compilation of Civil Law of Catalonia of 1984), and ends up being mere residual interpretative criterion as stated in the first law of the Civil Code of Catalonia.

In our opinion, this evolution is due to the fact that hermeneutic rules pertain more to Compilations and Recompilations than to Codes given that the latter, which attempt to regulate a sector of the legal system ex novo, tend to mistrust history and traditional legal thinking, preferring to entrust all of their meaning to the literal tenor of the regulations.

Regarding the systematisation of the Codes, 'in the compilations cohesion is achieved by interpreting diverse precepts according to identical principles. For this, hermeneutic rules cannot be disregarded'3 ${ }^{3}$. Thus, as Catalonia gains greater degrees of self-government and recovers its own Parliament it faces the challenge of codifying its civil law and, as a consequence, the role of the hermeneutic rules changes.

Now with the Parliament as the legitimate source of law in Catalonia, the former need to establish an interpretative system that eluded, wherever possible, appeal to other sources of legislation, including the Civil Code, has declined.

With no Parliament of its own, Catalonia had had to pursue a different policy, and while accepting that considering legal writing to be a source of law is incompatible with the constitutional order, 'if afterwards we do not recognise the doctrines of Catalan authors and their legal writing as sources of law, it will be impossible to deny them interpretative power for laws when questions arise about the true understanding of a particular institution and its effects'4

Nowadays, the importance of the hermeneutic concept Catalan legal tradition is declining given that there is now a Catalan Parliament that constantly modifies and updates the nation's civil laws. It is within this more peaceful context ${ }^{5}$ that we would like to reflect upon the value of the concept Catalan legal tradition as it evolved from the nineteenth century onwards and in relation to the emergence of what would become known as the Catalan Legal School.

\section{THE CONCEPT OF LEGAL TRADITION IN CATALONIA}

Before the law (source of Spanish national law), jurists of the Catalan Legal School ${ }^{6}$ considered custom to be the only source of law characteristic of free nations:

\footnotetext{
${ }^{3}$ Enrique JARDY CASANY: 'Regarding the hermeneutic rule of article 1 of the Compilation of civil law in Catalonia', in Revista Jurídica de Cataluña, LX-1, 1960, p. 17.

${ }^{4}$ Manuel DURÁN I BAS: Memoria acerca de las instituciones del Derecho civil de Cataluña,Barcelona, 1883. I cite from the facsímile edition published in the Collection of Catalan Legal Texts. t. 10, Projecte d'Apèndix i Materials Precompilatoris del Dret Civil de Catalunya, p. 11

${ }^{5} \mathrm{An}$ example of a more troublesome stance is that of Jesús LALINDE ABADíA in 1961. Cf. his work 'Study of article 1 of the Compilation of Civil Law specifically for Catalonia (Historical School of Law)' in Revista Jurídica de Cataluña, LX-1, 1961, pp. 249-272.
} 
Peoples who believe in the omniscience and the omnipotence of the State are those that only see law in the positive law dictated by the State, and they are always its slave, whether its sovereignty is in the hands of a king, of an oligarchy or of a democracy. Because peoples who believe in social forces as determinants of the State of law in which they are constituted put everything into these social forces and they do not fear the law which is dictated by the people through custom. These are the peoples who are truly free?

However, what is really novel about the thinking of the Catalan Legal School is their view that custom, as a fundamental source of law, shapes a type of legal writing that is considered to be the essential source of law in the legal system of Catalonia.

This legal writing, which was considered to be a fundamental source, manifestation of law, is simply the secular interpretation of the regulations. Legal writing thereby unites with customary law, through tradition ${ }^{8}$. As the eminent Dean of the Association of Notaries of Barcelona, Félix María de Falguera pointedly said:
Knowing the text of the dispositions is not enough to understand Catalan law in its true sense. One must look closely at the centuries-old interpretation that others have received. The Romans were right when they said 'Optima legum interpres est consuetudo', and it would not be appropriate for an attorney-at-law to insist on studying our municipal law by reading its laws and interpreting them according to his own criteria. This attempt, which has been observed for some time, this tendency to move away from interpretation sanctioned by custom simply leads to introducing anarchy into the law. Individual reason, wherever it is applied, will always produce the same results ${ }^{9}$.

Catalan law, therefore, can be defined as a customary and doctrinal law which interprets legal writing not as a rational, rootless reflection of the regulations, but as the application of intellectual commitment with one's own traditions to the understanding of the law.

For this, Félix María de Falguera affirmed the need to 'to know intimately the country where the customs were created, in order to be able to judge the goodness of them and their influence on the way of being and feeling in that country.'

\footnotetext{
${ }^{6}$ There is much bibliography about the Catalan Legal School. Especially recommendable, in our opinion, are the works of Juan VALLET DE GOYTISOLO': Cotejo con la Escuela Histórica de Savigny, Barcelona, 1980 (supplement of Revista Jurídica de Cataluña, nos. 3 and 4 of 1979 and 1, 2 and 3 of 1980); Montserrat FIGUERAS PÀMIES: La Escuela Jurídica Catalana frente a la Codificación española. Durán y Bas: su pensamiento jurídico-filosófico, Barcelona, 1987; and Antoni MIRAMBELL I ABANCÓ: 'Catalan Legal Schools and Codification', in V Jornades de Dret Català a Tossa. Cent anys de Codi Civil des de Catalunya, Barcelona, 1990, pp. 47-94.
}

${ }^{7}$ Ramón de ABADAL I CALDERÓ: 'Freedom in civil laws', in Revista Jurídica de Cataluña, XI, 1905, p. 13. Also, 'Freedom in civil law' in Revista Jurídica de Cataluña, IX, 1903, pp. 641-662.

\footnotetext{
${ }^{8}$ This is the theoretical framework that explains the appearance of a considerable number of theoretical works that were for use as study material in the institutions of private law in Catalonia from the perspective of the authors of the modern age. Examples are some of the works of MASPONS ANGLASELL such as: Nostre dret familiar, seguns els autors clàssics: Fontanella, Cancer, Mieres, Ferrer etc., 1899; or Nostre dret familiar, segons els autors clàsics i les sentències de I'antic Suprem Tribunal de Catalunya, 1907.

${ }^{9}$ Félix MARÍA DE FALGUERA: Conferencias de Derecho catalán dadas en el Ateneo Barcelonés en 1870 y 1880, Barcelona, $1889, p .10$. The italics are my own.
} 
This concept of the sources of Catalan law is consistent with historical events. Hardly any new regulations were promulgated after 1599 by the Catalan Cortes (parliament) in relation to civil law. Philip II (III of Castile) did not call for any meetings of the Cortes; no constitutions were completed nor new ones created under Philip III (IV of Castile); and Charles II did not call for any meetings of the Cortes either ${ }^{10}$. In fact, after the 1599 Cortes only one Constitution that refers to matters related to civil law can be found: the thirteenth Constitution of the Cortes of Barcelona in 1702, which referred to the contracts of violaris (annuities for life) ${ }^{11}$.

Bearing this in mind, it could be said that the Decree on The Establishment and the Nueva Planta Decree of the Royal Court of Justice of Catalonia of $16^{\text {th }}$ January 1716 simply consolidated a process that had been developing in the Principality throughout the entire seventeenth century. Catalan civil law has evolved from a basis of traditional regulation through jurisprudence and appeal to legal doctrine, mainly from abroad.

At the beginning of the eighteenth century the scanty regulatory basis of this tradition of Catalan civil law, which was so determined by a legal practice based on jurisprudence and doctrine, was laid down in a Constitution of the Cortes of Barcelona in 1702. This Compilation was fruit of the reprinting of the Compilations edited in the Principality in 1588 and 1589 with the additions of the Constitutions of the Cortes of 1599 and of the Constitutions approved by those that were held in Barcelona, all with updated indexes and alphabetic catalogues. This third General Compilation of Catalan Law was published in 1704 and is what the Supreme Court called Libro de las Constituciones de Catalunya (The Book of the Constitutions of Catalonia) ${ }^{12}$. This regulatory text left the importance of legal writing to Catalan law in no doubt, as illustrated by the tenor of the Constitution of the Cortes of Monzon of $1542^{13}$.

Therefore, the legal content of Catalan civil law was composed of quite a narrow traditional regulatory base, which was completed and updated by jurisprudential practice that was collated in the Colecciones de Decisiones ${ }^{14}$. To this was added the works of a Catalan doctrine with a dis-

\footnotetext{
${ }^{10}$ Guillem M.ade Brocà has spoken, then, of 'the era of immobilization of the law of Catalonia', highlighting the fact that as regulatory production is withdrawn the doctrinal evolution of the law is developed. Guillem M.a de BROCÀ: Historia del Derecho de Cataluña, especialmente del civil y exposición de las instituciones del Derecho civil del mismo territorio en relación con el Código civil de España y la jurisprudencia, Barcelona, 1918 (facsimile edition in the Collection of Catalan Legal Texts, Barcelona, 1985), p. 405
}

${ }^{11}$ CYADC [ Constitutions and other rights of Catalonia]-1704, I, VII, 11, 25.a (cf. Note no. 12).

$12 \mathrm{Here}$ we will use the edition of the Constitutions y Altres Drets de Cathalunya, Compilats en virtut del capitol de Cort LXXXII, de las Corts per la S. C. y R. Majestat del rey Don Philip IV, Nostre Senyor celebradas en la ciutat de Barcelona, Any MDCCII published in Barcelona in 1973. We will cite by using the initials CYADC, first indicating the year of the edition in order to distinguish this Recompilation from the previous two; then the volume, followed by the the indication of the Book, the title and the constitution that it is referring to.

${ }^{13}$ CYADC-1704, I, 1, 37, 1.

${ }^{14}$ Miquel FERRER, member of the Royal Court of Justice of Barcelona, was the first to complete this mission, publishing his Observantiae Regiae Audientiae circa formam dicendi causas in Audientia vertentes in 1580. Cf. Tomàs de MONTAGUT: 'Introductory Study', in Lluys DE PE- GUERA: Practica, forma y estil de celebrar Corts Generals en Cathalunya y materias incidents en aquellas, facsimile edition of that of Barcelona of 1701, Madrid, 1998, p. XXV. 
tinct personality, which was the consequence of the fact that its authors were not pure theoreticians, but practitioners of the law. Both doctrine and jurisprudence systematically used canon law and Roman law as their point of reference.

The importance, therefore, of legal writing in the formation of Catalan civil law is irrefutable ${ }^{15}$. 1599, the date previously mentioned as a point of reference, saw the drafting of a well-known Constitution, Del Dret se a de seguir en daclarar las causas, the only one of title 30 , book I, volume I of the Third General Compilation.

Here it must be mentioned that this openness to doctrine did at no point detract from the jurisprudential nature (practical) of Catalan law. Almost all the jurists we could name from the seventeenth century -Francisco Ferrer Nogués, Joan Pere Fontanella, Francisco Molí and many others were, first and foremost, practitioners of the law. In this way, jurisprudence and legal writing constituted an undissolvable partnership in Catalonia.

\section{THE TREND OF JURIDIC THOUGHT OF THE CERVERA SCHOOL IN THE EIGHTEENTH CENTURY}

Obviously, and as a logical consequence of everything we have previously discussed, it must be stated that in order to understand a legal system that has been constructed largely on the basis of legal writing and jurisprudence a study of the jurists that goes beyond a mere descriptive catalogue is called for ${ }^{16}$ : It requires an analysis of the methods and concerns of the Catalan jurists that have influenced the nature of Catalan law, which is perpetuated in the Compilation ${ }^{17}$.

In our opinion, the group of Catalan jurists that had the greatest influence on the development of the doctrine that modulates Catalan civil law, which would find itself enshrined in the 1960 Compilation, were those from the University of Cervera in the eighteenth century ${ }^{18}$.

The political situation after the Nueva Planta Decree did not bring about an abrupt change in the pace of development of a legal system which,

\footnotetext{
${ }^{15}$ Ultimately, we could say that Catalan civil law was shaped as a doctrinal law, given that the Constitutions could never expect to construct a more or less comprehensive system. On the contrary, it was conceived as a tool to be used sporadically to nuance or correct civil, canon, Roman law wherever necessary, which was taken to be the systematic basis of civil law in Catalonia. In this regard, Josep M. Pons Guri: 'Constitutions of Catalonia,' in Recull d'Estudis d'Historia jurídica de Catalunya, Barcelona, 1989.
}

\footnotetext{
${ }^{16}$ In this regard, the efforts of professor Tomás de MONTAGUT I ESTRAGUES, beginning in 1999, and his research project entitled 'The jurists and the law in Corona de Aragón. Centuries XIII-XVIII', approved by the General Directorate of Higher Education and Scientific Research of the Ministry of Education and Culture, must be highlighted. Reference BJU2000-0971, in which I collaborated.

We can find catalogues of Catalan jurists in Guillermo M.a de BROCÁ and Juan AMELL: Instituciones del Derecho civil catalán vigente, vol. I, Barcelona, 1882, Reseña histórica, ch. 3, sec. 6, p. 29; ch. 4, sec. 14, p. 70 et seq.; chapter. 5, section 7, p. 80 et seq.; ch. 6, sec. 4, p. 92 et seq. Also in Guillermo M.a de BROCÁ: Historia del Derecho de Cataluña, especialmente del civil etc, Barcelona, 1918, Historia, ch. III, sec. 11, p. 253; ch. IV, sec. 13, p. 386 et seq.; ch. V, sec. 7, p. 411 et seq.; ch. VI, sect. 5, p. 450 et seq.; and ch. VII, sec. 3, p. 467 et seq. There are also explanations in Bienvenido OLIVER: Estudios históricos sobre el Derecho civil en Cataluña, Barcelona, 1867, where we find a study (p. 177 et seq.) entitled De la jurisprudencia catalana. Noticia de jurisconsultos catalanes y de sus obras. Cf., similarly, José PELLA I FORGAS: Código civil de Cataluña. Exposición del Derecho catalán comparado con el Código civil, Barcelona, 1916, which was preceded by a Estudio de los elementos constitutivos del derecho catalán y del origen histórico de las instituciones, and a Estudio de la constitución formal o externa del derecho catalán, chapter IV of which deals with 'The legal writing of Catalonia in the XIX century and up to the present'. There are also data in Joaquín CAMPS I ARBOIX: Historia del Derecho catalán moderno, Barcelona, 1958, 'Bibliographic Outline' , p. 221 et seq. LastIy, cf. also Víctor FERRO: 'The Catalan jurists in the XVI and XVII centuries', a work which contains 'An Appendix. Jurists of the XVI and XVII centuries', published in Javier ALVARADO (ed.): Historia de la literatura jurídica en la España del Antiguo Régimen, Madrid, 2000, pp. 153-166.
} 
as previously stated, had been evolving through doctrine and jurisprudence and quite independently, to a large extent, of political and administrative bodies. In fact, on the contrary, the Nueva Planta Decree served to actually encourage this tendency.

It is certain that during the eighteenth century Spanish Universities tried to adapt the study programmes of their Law Faculties to the new political situation of absolute monarchy, which brought with it a greater presence of Spanish national law ${ }^{19}$. This process took on special significance in Catalonia and, in particular, at the University of Cervera, with some very peculiar and sometimes paradoxical consequences.

In 1771 Charles III started the drive to reform the universities, providing the Universities of Valladolid, Salamanca and Alcalá with new study programmes, and later doing the same for the Universities of Santiago, Granada, Valencia and Oviedo. In all of these programmes chairs were established for the study of Spanish national law, which marked the beginning of the very gradual decline of the study of Roman law in Spain ${ }^{20}$.

The study programme that had been introduced at the aforementioned universities, devised at the University of Salamanca and revised by the Prosecutor of the Council M. G. de Campomanes $^{21}$, was also implemented at Cervera University in Catalonia where it was to serve as a basis and guide for the reform of their existing study programme. This caused heated debate at Cervera, which resulted in an Informe, composed of a collection of reports on the specific areas of study of each faculty and some general questions to be discussed and settled in the university cloister ${ }^{22}$.

The Law Faculty's report that was included in the general Informe was of course inspired by who, at that time, was the most influential jurist at the University and who, without doubt, was the most influential professor in the Law Faculty: José Finestres de Monsalvo. To understand the content and meaning of the Informe, we must first allude to Finestres's importance as a jurist.

\footnotetext{
${ }^{17}$ In this regard, cf. Tomás de MONTAGUT: 'The legal system of the jurists of Barcelona in the Early Middle Ages', in Rudimentos legales. Revista de historia del Derecho, no. 2, 2000, pp. 63-91. James S. AMELANG: 'Barristers and Judges in Early Modern Barcelona: The Rise of a Legal Elite', in American Historical Review, no. 89-5, 1984, pp. 1264-1284. The unpublished thesis of Stephen S. JACOBSON: Professionalism, Corporatism and Catalanism: The Legal Profession in Nineteenth-Century Barcelona, Tufts University, 1988. Also, although it also covers other matters, Siobhan HARTY: 'Lawyers, Codification and the Origins of Catalan Nationalism, 1881-1901', in Law and History Review, vol. 20, no. 2, 2002, pp. 349-384.
}

\footnotetext{
${ }^{18}$ The statement can seem paradoxical, bearing in mind that until relatively recently historiographical tradition has made widespread the idea that the University of Cervera was an effective procedure through which Philip V attempted to impose his centralist ideas in the area of culture in Catalonia as well (see, cf. Ferrán SOLDEVILA: Barcelona sense Universitat i la restauració de la Universitat de Barcelona (1714-1837), Barcelona, 1938. L. B. NADAL: 'The resistance to centralist university teaching in Catalonia in brief', in Estudis Universitaris Catalans, Barcelona, 1907).
}

${ }^{19}$ In this regard, Mariano PESET: 'Roman law and Spanish national law in the universities in the XVIII century', in Anuario de Historia del Derecho Español, 45, 1975, pp. 273-339.

${ }^{20}$ Cf. Mariano and José Luis PESET: La Universidad Española (siglos XVIII-XIX). Despotismo Ilustrado y Revolución Liberal, Madrid, 1974.

${ }^{21}$ A study of the Plan of Salamanca and its influence, in Mariano and José Luis PESET: El Reformismo de Carlos III y la Universidad de Salamanca. Plan General de Estudios de 1771, Madrid, 1969.

${ }^{22}$ The Informe can be found in the library of the University of Barcelona, Archivo de la Uni- versidad de Cervera, box no. 318 , document no. 231. 
José Finestres was, first and foremost, a Romanist. Gregorio Mayans said to him in a letter that 'the Catalans have had great lawyers, but not until you did they have a great interpreter of Roman law23.' Finestres's Romanism could be described as traditionalist in the sense that he was a legal humanist, but this did not lead him to adhere to the iusrationalism of the time: On the contrary, he had little time for the new trends in natural law. He was known to have said.' Dear God, please do not let the errors of French romanticists and northerners regarding natural law be made here in Spain ${ }^{24}$.'

He was enormously sensitive to Catalan 'municipal' law, understood to mean the Catalan law which was upheld after the Nueva Planta Decree. In this sense, Finestres was a man of his time and he felt the need to foment and study Catalan law, but from the categories and methods of Roman law. From his correspondence with Mayans we know that he was working on two compositions, one entitled Iuris catalauni elementa, relata ad certos locos institutionum Iustiniani which aimed, as the title suggests, to study Catalan law from within the conceptual framework of the Institute of Justinian; and the other entitled Historia iuris catalauni 25

Poor health would prevent Finestres from finishing these works and there only remained some drafts of the Historia iuris catalauni and a manuscript of luris catalauni elementa, which according to Luciano Gallissá was fairly complete but which is now, unfortunately, lost ${ }^{26}$.

It was precisely because of his teaching position at the University of Cervera that as early as 1749 the need to explain Roman law with all its concurrences and discordances with respect to Catalan law came to be clearly represented in its Statutes ${ }^{27}$. This requirement was brought about by the well-known General Provision of $29^{\text {th }}$ May 1741 in which Philip V insisted that the Laws of the Realm corresponding to the matter' be explained 'with Roman law.'

The University's observance of this order brought about a certain paradox: it actually strengthened and rooted more deeply, if that was possible, traditional Catalan law at the expense of Spanish legal centralism which, of course, was precisely the opposite of the desired effect. It could have been no other way given that in Catalonia 'the laws of the Realm' in matters related to civil law, even after the Nueva Planta Decree, were those of the Catalan legal tradition.

And so in Cervera the Catalan legal tradition connected with the new times; with the cultured, humanistic Romanism linked to Spanish national law (Royal Castilian law) as represented by authors such as Heinecio and Vinnio. Finestres was the first manifestation of this process, the first Catalan personification of the transformations that university law studies underwent in the eighteenth century: the break with the late mos

23. CASANOVAS: Josep Finestres. Estudis biogràfics, Barcelona, 1931, p. 255.

24. CASANOVAS: Documents per la Història Cultural de Catalunya en el segle XVIII. Josep Fi- nestres. Epistolari, Barcelona, 1964, vol. II, letter 971, and also vol. I, letter 408.

${ }^{25}$ The letters to Gregorio Mayans in which these works are mentioned (letters dated December 1728 and February 1749 ) in I. CASANOVAS: Josep Finestres...etc. pp. 431-432.

${ }^{26}$ Cf. Luciano GALLISSÁ: De vita et scriptis losephi Finestres et a Monsalvo...etc.Cervera, 1802.

${ }^{27}$ Specifically, statute 8.oof title XI of the University of Cervera (overseen by Royal Order of 2nd October 1749) made law professors responsible for explaining changes and existing differences between Roman law and municipal law. 
italicus, the incorporation of the values of legal humanism from a traditionalist stance that kept it apart from natural rationalist law, and the contemplation of Spanish national law at the core of the study programmes.

Several of Finestres's works testify to this fact. His Exercitationis academiae (...) lib. I Epitomarum iuris Hermogiani, published in 1745, and his 1750 Exercitationis academiae, contain important developments of a very well-worked legal humanism. Furthermore, his work De iure dotium livri, published in 1754, was a comparative study of the Roman, canon and Catalan systems. And in his celebrated work In Hermogiani I. C. Iuris epitomarum libro VI, published in 1757 , he was able to study, from the thinking of the most erudite legal humanism, the work of the Roman jurist. This was accompanied by twelve dissertations on natural law which gave him the opportunity to give form to traditional Catholic values (which, of course, had nothing to do with rationalist natural law as represented by Hobbes, Grocio, Pufendorf and Wolff).

In fact, Finestres believed in a reworking of Roman law studies from the perspective of legal humanism, the fostering of natural law understood as a defence of Catholic values and, which was the icing on the cake, a renewed interest in Catalan law according to the concepts of legal humanism and traditionalism.

In light of this analysis of the figure of José Finestres, the content of the Informe compiled by the University of Cervera in 1772 regarding the reform of the teaching of law comes as no surprise. Basically, law studies were to be organised from three perspectives: Firstly, Roman law would continue to form the basis of the training programme for jurists. In fact, Roman law would be taught exclusively until baccalaureate. Second- ly, the study of Catalan law and canon law - a source of law in Catalonia according to the weII-known Constitutions of 1409 and 1599 - would be fomented. In fact, the two years of study that led to graduating in law were to be dedicated to the study of these two legal systems. Thirdly, and totally contrary to what was happening in other study programmes such as those of Valencia and Granada Universities, nothing was said in the Informe of the University of Cervera about introducing the study of natural law.

To say that this proposal is conservative because of its fervour for Roman law is unfair ${ }^{28}$. As discussed earlier, civil law in Catalonia was an essentially doctrinal and jurisprudential tradition developed from Roman and canon law and applied to its own particular institutional base. Therefore, a study programme such as that proposed by the University of Cervera did not necessarily mean disregarding Catalan law; in fact, on the contrary, it strongly defended Catalan law in the face of the upsurge in Castilian Bourbonic centralism. And it was precisely because in Cervera the idea of investigating 'national' law in further depth meant rejecting modernity as represented by the Bourbons that the simultaneous rejection of European rationalist natural law was actually quite consistent.

Ramón Lázaro de Dou Bassols was another important Catalan jurist to emerge after the Nueva Planta Decrees and the transferral of all law studies in Catalonia to the University of Cervera. He demonstrated that a position of franc adhesion to Bourbonic absolutism was not necessarily contradictory to the cultivation and development of Catalan law based on doctrine and jurisprudence. He affirmed that, on the one hand, 'there is no doubt (...) that the desire to put our legislation in order is indisputable for sovereigns, with

${ }^{28}$ Claim made by Joaquim PRATS in his otherwise valuable work. La Universitat de Cervera i el reformisme borbònic, Lleida, 1993, p. 295 
everything pending their discretion and will'29 but, on the other hand, he also defended maintaining Catalan law and the theory that Roman law should substitute civil law in Catalonia before Castilian $\operatorname{law}^{30}$.

The figure of Joan Antoni Mujal de Gibert must also be highlighted. In his Annotationis, bene multis indicatis fontibus ex quibus aquam haurire liceat published in Cervera in 1781, he developed a treatise of Roman law (an analysis of the institutions of the Digesto) making reference to the relevant regulation in Catalan law (In hoc Principatu, Patrio Cathalaunia iure, etc.) at the end of each chapter. These regulations depended not only on the Usages and the Constitutions of Catalonia, but also on custom and classic Catalan doctrine. In this way, the solutions of Cáncer, Fontanella, Ripoll, Mieres, etc, appear as Catalan laws.

If his excessive pro-Bourbonic ${ }^{31}$ stance makes him consider the order of preferences for sources stipulated in the Constitution of 1599 null (bearing in mind that Brocà considers this theory to be simply political opportunism ${ }^{32}$ ), his work in fact clearly fits into the framework of a Catalan tradition always shaped within the Roman-Catho- lic order which, in the absence of specific Constitutions, turns to the traditional legal doctrine of the territory and to customary law to solve problems arising from legal omissions.

There are more examples. After the Nueva Planta Decrees, jurists from the University of Cervera continued to cultivate a Catalan law characterised by its doctrinal personality, a personality that would now acquire the specific, new traits of the University of Cervera. Authors like Poncio Cabañach, Francisco Grases Gralla, José Grau de Sunyer, Antonio Juglá Font, Juan Antonio Torres Casana, Jaime Tos Urgelles, Antonio Pastor, Lorenzo Santayana and Vicente Gibert certainly prove the point ${ }^{33}$ and even justify Torres Bages's affirmation that: 'The University of Cervera preserved a Catalanism that I wish we could still find nowadays in the University' ${ }^{34}$

The University of Cervera's defence of the importance of Roman law even continued throughout the nineteenth century, which was not the case in other universities of the realm. There was a particular reason for this: in Catalonia, to defend Roman law was to defend Catalan law against Castilian law, since 'the civil legislation of Catalo-

\footnotetext{
${ }^{29}$ Ramón Lázaro de DOU Y DE BASSOLS: Instituciones de Derecho Público General de España con noticia del particular de Cataluña y de las principales reglas de gobierno de cualquier Estado, Madrid, 1800, I, p. 82.
}

30In this regard, the Memorial that made reference to the king in 1822. Cf. Bienvenido OLIVER: Estudios históricos sobre el Derecho civil de Cataluña, Barcelona, 1867, p. 99 et seq.

${ }^{31}$ The title of one of his works is ample proof of this: Desengaño al público con pura y sólida doctrina. Tratado de la Observancia y obediencia que se debe a las Leyes, Pragmáticas sanciones y Reales Decretos; y ninguna fuerza, en nuestro estado monárquico, de las costumbres, que, sin consentimiento del príncipe, se introducen en contrario, e interpretaciones que se dan por los súbditos; y finalmente que no depende el valor y la fuerza del soberano, de la aceptación de los súbditos, ni éstos tienen libertad para dejar de aceptarla y observarla, published in Cervera in 1774.

${ }^{32}$ Guillermo M.a de BROCÀ: Historia del Derecho de Cataluña, especialmente del civil, y exposición de las instituciones del Derecho civil del mismo territorio en relación con el Código civil de España y de la jurisprudencia, Barcelona, 1918, p. 453.

${ }^{33}$ Information on all of these authors in Bienvenido OLIVER: Estudios Históricos sobre el Derecho civil en Cataluña, Barcelona, 1867, 204-208. BROCÀ: Historia del Derecho de Cataluña, p. 453 et seq. Joaquín de CAMPS Y ARBOIX: Historia del Derecho Catalán Moderno, Barcelona, 1958, pp. 32-48.

34 Josep TORRAS I BAGES: 'The Catalan Tradition', in Obras Completas, Barcelona, 1935, VI, vol I, p. 263. 
nia consists mainly of what its jurists call supplementary law. ${ }^{35 \prime} 1815$ saw an event that would lead to a major legal revolt in Catalonia. The Mayor of Figueras consulted the Court of Barcelona about what the supplementary law in Catalonia was, the ius commune or the New Recompilation, as he needed to consult it to resolve a law suit. The Court, after hearing the public prosecutor, decided to take counsel from a higher power, the King, through the Ministry of Grace and Justice. The consultation was informed by the Council of Castile, who agreed that the Court should put together a 'compile' on the matter.

To this end, the Audience commissioned a group of lawyers - Agustín Tamaro, Francisco Tomás Ros, Juan de Balle and Juan Francisco Besora - who ruled in favour of maintaining customary law as the fundamental source of law in Catalonia. In the same expedient the public prosecutor also concluded the matter by pronouncing that a proclamation on the issue was no longer necessary 'supposing that the object of this expedient in the form that it took when the Constitution was published no longer exists'.

He was referring to the fact that when the Constitution was published in 1812, bearing in mind the order of article 258 about unifying civil legislation, 'the expedient had an objective.' In this way, he left it very clear that in Catalonia, quite contrary to what was happening in Castile, the fight to retain the study and validity of Roman law was the fight for 'national' law ${ }^{36}$.

At Cervera, as at other universities, the work of the jurists was not only conservative, but also creative, so that onto the Catalan law that they were conserving they also projected their own particular personality: that of the traditional Catholicism of the Catalan ruling class of the eighteenth century, a bourgeoisie that existed perfectly adapted to and fully integrated into the core of the Old Regime. To give an example, the 1794 prohibition of the chairs of natural law and of the law of nations had no repercussions whatsoever in Catalonia for the simple reason that these studies had never actually taken hold at Cervera.

Cervera's resistance to the reform of university law teaching imposed by the Royal Orders issued by Minister Caballero in 1802 is understandable, given that the aim of the Orders was to reinforce the study of Castilian law, making this the purpose of certain text books ${ }^{37}$, such as the work of Ignacio Jordán de Asso and Miguel de Manuel 'Instituciones del Derecho civil de CastiIla' .

These Royal Orders lengthened law studies to ten years; four years for the study of Roman civil law, four for the study of Spanish national law, or Royal Castilian law, and two for a work placement. The Spanish national law exam was based on the work of Asso and de Manuel, the nine books of the Castilian Recompilation and some other historical-legal books ${ }^{37}$. However, even though the effects of the 1802 reform reached Cervera immediately (by means of a Royal Order that imposed the teaching of the 'laws of the Realm' on Prima's two chairs), the trajectory of the Faculty of Law of Cervera remained immutable.

\footnotetext{
${ }^{35}$ Bienvenido OLIVER: Estudios históricos sobre el Derecho civil en Cataluña, Barcelona, 1867, p. 5.

${ }^{36}$ All of this process, from the Court consultation to the report compiled by the public prosecutor, in OLIVER: Estudios históricos, pp. 65-91.

37 In this regard, cf. Manuel MARTíNEZ NEIRA: El estudio del Derecho. Libros de texto y planes de estudio en la Universidad contemporánea, Madrid, 2001.
} 
The main aim of the Faculty of Law of Cervera continued to be basically the study of Roman-canon law 38 ; a Romanism, of course, that served the best European humanists, given that from 1802 the Chairs of Digestum Vetus and Volumen parvum used the works of Voet, 'Cujjacio', Domat and Gother (the choice being influenced, of course, by Finestres) ${ }^{39}$.

An internal report presented to the cloister on 20th January 1807 declared that the teaching of the 'laws of the Realm' in the Faculty of Law of Cervera were only accepted in a very limited and resigned way; they would be taught during the two years of work placement and fourth year students would be given 'some notions of public law through the Commentaries of Antonio Pérez.' It would seem that the order to impart the laws of the realm through Prima's chairs was quite ineffective.

\section{THE CATALAN LEGAL SCHOOL}

While Catalan law, as we have seen, was certainly secular and doctrinal in nature, it wasn't until the last third of the nineteenth century that expression 'Catalan Legal School' began to be used to refer to the group of jurists who refined and projected the true legal tradition of the country from the basis of legal writing. Clearly, in an historical age like the one in question, the emergence of this group was no coincidence.

The first to use the term 'Catalan Legal School' was none other than Manuel Durán Bas in a speech to inaugurate the new academic year of the Academy of Jurisprudence and Legislation of Barcelona, read on 1st February 188340: 'it is irrefutable that there is in Catalonia a common underlying base of legal ideas, a scholarly process that has almost always been adopted, a general tendency at the core of their legal institutions, criteria which, if not exactly the same, converge to resolve the legal problems that arise'.

Durán Bas even cites some names of important figures: 'Samponts is the philosopher, Vives the commentator, Martí de Eixalá the treatise writer, Permanyer the orator and Reynals Rabassa the inciter of controversy. Rey has elevated the School with the authority of the magistrate and Ferrer Subirana with the eloquence of the publicist, Anglasell with the knowledge of the teacher and Illa Vidal with the beautiful victories of the polemicist of the forum'.

While the Catalan Legal School was, in the last third of the nineteenth century, an emerging power (according to Durán Bas, 'if it is not yet virile, it has certainly reached the phase of full-blown adolescence'), its members did not wish to consider themselves distinct from the tradition of the Catalan jurists of the Middle Ages and the modern era, and they could not do so without breaking with a tradition which, in its very thinking, fundamentally linked legal writing and customary law. Therefore, according to Durán Bas, the CataIan Legal School merged with the Catalan jurists of Mediaeval times and the modern era in fostering the law within certain parametres: ' they tend to give private law priority over public law (...), and they also tend to yield to positive law and to shy away from all philosophical lucubration.'

Durán Bas thus portrayed the Catalan Legal

\footnotetext{
${ }^{38}$ From the reports of the faculty of 1803 it can be deduced that all of the Chairs continued to teach Roman law. Library of the University of Barcelona, Archivo de la Universidad de Cervera, box. no. 61, document 3068.

${ }^{39}$ Library of the University of Barcelona, Archivo de la Universidad de Cervera, box no. 295, document 118.

${ }^{40}$ Manuel DURÁN I BAS: 'The Catalan Legal School', en Estudios jurídicos, Barcelona, 1888, pp. 347-374.
} 
School in two ways. First, the tendency to give private law priority over public law' which meant that in relation to the monarchy they just pretended to maintain the institutions of civil law that Philip V's Nueva Planta Decree had declared to be in force, taking for granted that in no way were they on the road to aspiring to new political and administrative autonomies. And second, this shying away from 'all philosophical lucubration' meant a ratification of the values of traditional Catholicism as opposed to the new ideological currents that were sweeping Europe.

Durán Bas's two-pronged portrayal of the Catalan Legal School was much more in keeping, as we have seen, with the legal tradition of the University of Cervera than with the Catalan jurists of the sixteenth and seventieth centuries, who would never have considered renouncing public law in the political terms that were being used now in relation to the Bourbon monarchy, nor were they in a position to renounce 'philosophical lucubration' as it had not yet reached them.

The pending question is, what was this group of jurists' objective? What were they trying to achieve? What did they aspire to? The answer is clear:

The outcome of our study must be the strengthening of regionalist ideas, which tend to preserve the way of being of the counties and the nations, to fight tooth and nail against the Caesarist tendencies of revolutionary egalitarianism, which is conceived by the pagan renaissance ${ }^{41}$.

A similar allegation was made by Ramón $\mathrm{M}^{\mathrm{a}}$ Catá de la Torre in his work dedicated to the study of Catalan customary law, which was awarded a prize by the Academy of Jurisprudence and Legislation of Barcelona in 1914. In this work he, of course, reinforced Durán Bas's two-pronged portrayal of the Catalan Legal School which, as we have seen, came directly from the legal thinking of the Cervera School: their own legal tradition in relation to civil order and traditional Catholicism as opposed to new ideological tendencies.

This set of well-developed and interrelated principles and arguments, criteria and definitions developed by the members of the Catalan legal School was presented as an expression of the historical tradition of the people. Law, as Durán Bas said, 'is history' and 'law informed by the national spirit of the peoples is the doctrine usually asserted by the Catalan Legal School' ${ }^{42}$.

In this way, Catalan Law, as described by the jurists of the Catalan Legal School acquired a transcendent, and therefore, unquestionable base.

In the middle of the nineteenth century this historical tradition was presented as a defensive bastion against the uniformist ambitions of the State and their eagerness to codify Spanish law. The legal argument used went back to the thinking that had been articulated previously at the University of Cervera by the Catalan ruling class of the eighteenth century, who had been incorporated by modernity whilst at the same time remaining comfortably within the Old Regime. The role of the Catalan Legal School in such tumultuous and uncertain political times as the middle years of the nineteenth century would be, from a social, political and economic point of view, very clear.

It is quite obvious that the priority of part of the effort of the Catalan Legal School was to

\footnotetext{
${ }^{41}$ Ramón M.a CATÁ DE LA TORRE: 'Reasoned and critical explanation of the legal customs of the Principality of Catalonia or of some of its principal counties', in Revista Jurídica de Cataluña, XXI, 1915, p. 509.

${ }^{42}$ DURÁN I BAS: 'The Catalan Legal School', p. 364.
}

Spanish Journal of Legislative Studies, Núm. 1, 2, pp. 1-40. 
combat tendencies generated in Catalonia itself regarding the 'the social question', regarding revolutionary social and political thought that was threatening certain traditions. These efforts were concealed wherever possible as never was it admitted that doctrine would be expounded through a School that consolidated the liberal traditionalist evolution of Catalan law as if it were the only possible and authentically Catalan one.

It is precisely because of this attempt at concealment that certain historiography has made so much of the need to unveil this 'sinister', as well as hidden, aspect which was the material interests found underlying the legal pretensions of the Catalan Legal School. This, though, has led to a certain reductionism in their thinking, with some authors settling for portraying the Catalan Legal School as an instrument of the large Catalan landowners to defend their annuities and a system of testamentary law that guaranteed the indivisibility of their landed property. While this may be so, the fact is that the programme of the Catalan Legal School formed part of a much wider social, political, legal and philosophical project. It was a way of seeing the world that was encapsulated in the Appendix of the Civil Code through the Memoria that Manuel Durán Bas presented before the General Commission for Codification.

\section{THE CATALAN LEGAL SCHOOL AND CODIFICATION}

An examination of the stance of the Catalan jurists in relation to the codification process of civil law in Spain ${ }^{43}$ is revealing, as this stance was neither united nor did it remain constant throughout the nineteenth century ${ }^{44}$.

When the Cadiz Constitution was in force, aside from what happened in relation to the Bayonne Statute ${ }^{45}$, Catalan jurists were not at all opposed to the codification process, in fact they were quite open to the idea.

Several Catalan members in the Cortes of Cadiz were to become important figures as a result of their links with the law. The first was José Espiga Gadea, Archdeacon of Benasque, who was appointed by the Superior Assembly of Catalonia. Then, the towns and cities chose, among others, Antonio de Campmany de Montpalau, Ramón Lázaro de Dou Bassols and Ramón Utgés (both professors at the University of Cervera), Jaume Creus and the lawyer Felipe Aner de Esteve ${ }^{46}$.

Their task, as laid out in the Instructions to members provided by the Assembly, makes for

\footnotetext{
${ }^{43}$ From the point of view of the governments of Madrid, the book El Código civil en sus relaciones con las legislaciones forales, Madrid, by Manuel ALONSO MARTÍNEZ, who was Minster of Grace and Justice several times, was most illuminating (the edition that I use, published by Plus Ultra and with a prologue by José Castán, does not give a year of publication).

${ }^{44}$ This study was carried out by Antoni MIRAMBELL: 'Catalan Legal Schools and Codification', in V Jornades de Dret Català a Tossa. Cent anys de Codi Civil des de Catalunya, Barcelona, 1990, pp. 72-90.

${ }^{45}$ The date that the representatives of Vizcaya, Álava, Guipúzcoa and Navarra, achieved, by means of an amendment, the recognition that 'the specific rights of Navarra, Vizcaya, Guipúzcoa and Álava will be examined in the first Cortes to determine what is judged to be most suited to the interests of the aforementioned provinces and for the nation', is most interesting (art. 144 of the Statute); however, when the representative for Catalonia, Joseph Garriga y Buach, put forward the same question, President Azanza answered with a definitive 'no', given that Catalonia was considered not to have a Constitution of its own within Spain. Cf. Juan Francisco LASSO GAITE: Crónica de la Codificación Española, 4, Codificación civil (Génesis e historia del Código), vol. I, Madrid, 1980, p. 53, note no. 15.

${ }^{46}$ Federico RAHOLA: Los Diputados por Cataluña en las Cortes de Cádiz: Memoria leída en la Real Academia de Buenas Letras de Barcelona el día 23 de diciembre de 1911, Barcelona, 1911, pp. 20 et seq.
} 
interesting reading:

Even though, certainly, one must recognise the political advantages of unifying legislation and the rights of all the Provinces of the Monarchy so that after the current crisis what remains is not a single body composed of heterogeneous parts, even though many do not agree, or when insurmountable obstacles impede the realization of this healthy measure; in such case Catalonia must not only preserve its privileges and current regional laws, but it must also recover those it enjoyed when the Spanish Throne was occupied by the ancient house of Austria; considering the incalculable sacrifices that are being made in defence of the Nation it deserves to recover its privileges ${ }^{47}$.

With this order, which we must remember came from the Superior Assembly of Catalonia, the question of the need to codify and make uniform the law would, of course, be nuanced by Catalan members of the Cortes whenever the matter arose.

The first of these occasions came about in the session of 5th February 1881 when member of the Cortes José Espiga, who as you will recall was appointed directly by the Superior Assembly of Catalonia, proposed that different parliamentary commissions should be set up to plan the necessary legislatory reform. He suggested that one of these commissions should be assigned the task of 'reforming civil legislation' and another should reform penal law ${ }^{48}$. Thus, the matter of the unification of the law was brought to the fore.

The Catalan member of the Cortes and lawyer Felipe Aner de Esteve who, as Secretary of the
Assembly, had written the aforementioned Instructions provided to Catalan members, intervened in the matter of Espigas's proposal, affirming that 'a nation with one sole religion and one sole king must also have the same laws', and reminding the house that 'legislation is made for the people in accordance with the customs and circumstances of their lives'. He concluded by affirming that commissions 'for each province' were needed to carry out legislative reform as 'there are different uses in each of them'.

Like Aner de Esteve, the eminent Chancellor of the University of Cervera Ramón Lázaro de Dou Bassols intervened in the matter by pointing out the difficulties involved in carrying out legislative reform as proposed by Espiga without actually opposing the latter's principle of a single nation and a single system of law. He argued that to carry out this kind of reform 'all the Codes of our legislation' should, of course, be taken into account, but he also pointed out that many circumstantial factors had not been expected: the difficulties of wartime, the island of

San Fernando, the Constitutions of Catalonia and the Aragonese and Navarran laws, to name a few. And so without actually formally opposing the idea of 'national' legislative reform (which would have been seen as rather unpatriotic) Dou Bassols dared to recommend that, bearing in mind the aforementioned current difficulties, the most appropriate measure would be to follow the prudent criteria of Philip $\mathrm{V}$ and maintain traditional law with certain limitations ${ }^{49}$

When what would become article 258 of the Constitution of 1812 was being debated member of the Cortes Leyva intervened on behalf of the

\footnotetext{
${ }^{47}$ RAHOLA: Los Diputados por Cataluña, p. 53.

${ }^{48}$ Diario de Sesiones de las Cortes Generales y Extraordinarias, Madrid, 1870, I, p. 500.

${ }^{49}$ Diario de Sesiones de las Cortes Generales y Extraordinarias, I, p. 502.
} 
ruling Commission stating that 'the Commission considers that (...) some peoples of the Peninsular and Ultramar, because of their particular circumstances, could demand a statute for their own requirements which others do not need. [The Commission] recognises that some kind of variation is necessary ${ }^{\prime 50}$. As a result, this well-known article reads: 'The civil, penal and commercial Codes will be the same throughout the monarchy, without being detrimental to the variations which, for particular circumstances, the Cortes may make.'

These 'variations' of the Codes according to article 258 were potentially quite extensive. Furthermore, the fact that they were indeterminate and not classified into some type of numerus clausus meant that the aspirations for the continuity of all the legal systems of the monarchy could be met. The reproach of member of the Cortes Zacatecas Gordoa Barrios was enough to justify how Catalan members would interpret this article:

Only the uniformity of laws can make the Codes one and only (...) By not classifying the variations the door is left open, and not slightly open but wide-open, as wide as one wishes (...), to the spirit of provincialism which, far from promoting uniformity, seeks, on the contrary, to maintain without question practices and customs which in bygone times may have been laudable but will now only serve to weaken and break the sacred link that must unite all the Spains ${ }^{51}$.

The criteria introduced in article 258 was, of course, more about recognising the legal and political peculiarities of foreign territories, but it also served to give differences on the peninsula the opportunity to survive. It also meant that the claims made by of Catalan members would this time pass less noticeably, subsumed as they were by the force with which particularism was being revindicated in the Americas.

What seems to be beyond question is that at the beginning of the nineteenth century, after the reading of the parliamentary Acts on the matter, the stance of the Catalan jurists was mixed. On the one hand, the new era ushered in by the nineteenth century was a temptation that the Supreme Central Assembly of Catalonia ${ }^{52}$ could not resist but, on the other hand, their old attachment to their traditional institutions and historical law was still very much alive.

Codification was, in any case, defined according to article 258 of the Constitution, with due respect and 'without being detrimental to the variations which, for particular circumstances, the Cortes may make.' Thus, the codification process at that time did not constitute an attack on CataIonia. In fact, the codification of commercial law in 1829 occasioned hardly any opposition from historicist or patriotic thinking.

The Constitution of 1837 displayed a rather less open approach to the codification process. Article 4 read: 'Some codes will apply to the whole of the monarchy, and for these a single code of law will be established for all Spanish peoples for ordinary, civil and criminal trials.'

The imperative of article 4 of the constitutional text, however, was no impediment to an eminent member of the Catalan Legal School (according to Duran Bas himself) agreeing to accept the po-

\footnotetext{
${ }^{50}$ Diario de Sesiones de las Cortes Generales y Extraordinarias, III, p. 2306.

${ }^{51}$ Ibid.

${ }^{52}$ As we have transcribed from the Instructions provided to members of the Cortes by the Assembly: 'one must recognise the political advantages of unifying legislation and the rights of all the Provinces of the Monarchy so that after the current crisis what remains is not a single body composed of heterogeneous parts'.
} 
sition, no less, of spokesperson for the Commission set up to compile the Civil Code. And so by Decree on $16^{\text {th }}$ December 1837 Joaquim Rey was appointed to this position of a Commission whose task it was 'to make the laws and civil practices of the entire monarchy uniform as set out in article 4 of the Constitution under the principle of national unity, and to preserve the laws and expectations founded in the laws and special regions to which end the means to achieve the desired uniformity will be proposed ${ }^{53}$.

So it is quite clear that at this time the codification process was not

interpreted as an attempt to eradicate regional legal diversity in the State, or at least it was not feared as such in Catalonia.

Once the General Commission for Codification was created by Royal Decree on $19^{\text {th }}$ August $1843^{54}$ it approved a General Basis for codification $^{55}$. The second point said 'In accordance with the fourth article (of the 1837 Constitution) no special regulations will be recognised in the Codes, except for reasons of things or matters, thus establishing itself as the only regulation in civil and criminal trials in all the Spains.' In a similar vein, the third point stated: 'The Civil Code will embrace the necessary dispositions so that in its implementation in provinces that have special legislation the acquired rights or even the hope created by legislation is not jeopardised ${ }^{56}$,

Domingo María Vila ${ }^{57}$ intervened before the Commission on $20^{\text {th }}$ September 1843 in relation to the sensitivity to certain provinces' 'special legislation' as required by the Civil Code. He raised the question that point 2 needed to be revised to include the comment,'respecting existing laws and customs wherever possible.'His aim was to achieve a codification which would reserve areas of diversity for the different regional traditions of the State, saying that while he recognised that uniformity was of great benefit to judges and governments the laws had to balance these advantages against 'the well-being of the different provinces that are important to Spain, which are today prosperous and thriving under the wing of the State's protective laws'58. Thus were introdu-

${ }^{53}$ LASSO GAITE: Crónica de la Codificación Española, 4, Codificación civil, vol. l, p. 151.

${ }^{54}$ The text of the Decree, in LASSO GAITE: Crónica de la Codificación Española, 4, Codificación civil, vol. I, p. 152, note no. 4.

${ }^{55}$ Cf. LASSO GAITE: Crónica de la Codificación Española, 4, Codificación civil, vol. I, pp. 154-155.

${ }^{56}$ Cf. José Antonio ELÍAS: Compendio de la Historia de las Instituciones y Derecho de la Mo- narquía Española y de cada uno de los Reinos en que estuvo dividida, Barcelona, 1847, pp. 547-549.

${ }^{57}$ Catalan, Professor of the University of Barcelona, Chief of Administration and Attorney of the College of the Court; was member of the Cortes for Barcelona in the terms of 1836 and 1841; as a member of the Commission he was very influential regarding the Constitutive Law of the Tribunals of 1845 and the Penal Code of 1848 . His speech to the Commission about the way to understand the 'unity of codes' that the Constitution claimed was published in El Faro Nacional, no. 107 (1852), pp. $401-408$.

${ }^{58}$ Cf. LASSO GAITE: Crónica de la Codificación Española, 4, Codificación civil, vol. I, pp. 155-156.

${ }^{59}$ In this regard, Cf. Pablo Salvador CODERCH: La Compilación y su historia. Estudios sobre la codificación y la interpretación de las leyes, Barcelona, 1985, pp. 14-15. Cf. LASSO GAITE: Crónica de la Codificación Española, 4, Codificación civil, vol. I, pp. 154-156, 299.

This peculiarity - a civil code that allowed room for regional diversity and the survival of various alternative legal systems that were in force at the same time as the one established by the code - was unique and exceptional in Europe. Nowadays, it arouses increasing curiosity and comment. Cf. Kenneth F. LEDFORD: 'Codification and Normativity: Catalan 'Exception' and European 'Norm', Law and History Review, vol. 20, no. 2 (2002), pp. 385-392. 
ced what years later would be called the Regiona Appendices ${ }^{59}$.

There was no room for members of the $\mathrm{Ci}$ vil Code Section of the Commission to think that that they were working towards a project that ignored the different regional traditions of the State. Other members of the Section aside from Domingo María Vila, who was a professor at the University of Barcelona, were Javier de Quinto who upon taking up his position as spokesperson declared that he was going to represent the 'private interests of the peoples of the ancient Kingdom of Aragon' - and Florencio García-Goyena, a Navarran who had been a member of the Cortes for this regional province from 1839-1840, as President.

As Antoni Mirambell points out, until the publication of the Civil Code Project in 1851 there was generally no reticence about the codification process in Catalonia ${ }^{60}$. This situation, however, changed radically with the Royal Orders of $12^{\text {th }}$ June 1851 and $3^{\text {rd }}$ January 1852, which submitted the Project to the opinion of institutions, authorities and jurists with the aim of improving the text.

The publication of the Project in 1851 caused great fear in Catalonia mainly, as some authors have pointed out, among rural landowners who believed that the Project threatened their annuities, which were declared redeemable, as were their family economic traditions, given that the Code imposed the rigid Castilian system of 'legitimas', or forced heirship.

According to the aforementioned authors, rather than focussing on exactly what they were defending - the conservation of certain institu- tions - a legal defence was mounted within the framework of the growing Catalan traditionalism that was stimulating the Renaissance. This meant that the group of jurists that were defending the rural landowners of Catalonia appeared to also be defending the only national legal tradition of the country worthy of being called such, and so from this position they were questioning not just specific legal institutions but the concept of the codification process itself. ${ }^{61}$

The true cause of the conflict, however, went much deeper. The controversy over economic interests, which undoubtedly existed, was just one aspect of a much more complex problem, which could in no way be reduced to a struggle over land ownership.

A comprehensive and systematic sample of this programme entitled El Dret Catala i la Codificacio: Report presentat al Consell Permanent de la Mancomunitat de Catalunya (Catalan Law and Codification: Report presented to the Permanent Council of the Commonwealth of Catalonia) was published by the Oficina d'Estudis Jurídics de la Mancomunitat de Catalunya. This work - which has received surprisingly little attention from scholars of history and Catalan law - came to light once the process of the Codification of civil law was irreversible (it was published in Barcelona in 1919) and it develops a concept of Catalan law which starts from the premise of an organic idea of society and freedom quite contrary to the usual criteria of individualist liberalism. In this work, published in middle of the twentieth century, the Oficina d'Estudis Jurídics de la Mancomunitat summarised the conclusions of Catalan

\footnotetext{
${ }^{60}$ MIRAMBEL: 'Catalan Legal Schools', p. 76.

${ }^{61}$ In the words of Salvador Coderch: 'Despite everything it is precisely this rejection of some aspects of the Project that are considered to be fundamental that encouraged the voicing of the first global criticisms of Codification from a doctrinal point of view - or, if one prefers, from an ideological point of view - as a system for regulating civil relations of a people, and specifically, of the Catalan people', Salvador CODERCH: La Compilación y su historia, p. 87.
} 
legal thought, which had largely been forged the previous century, and this served as the basis for solid opposition to the Civil code and for fostering the objective of maintaining and developing Catalonia's own law.

This publication clearly illustrates that the opposition to the Codification of civil law in Catalonia can only be fully understood by turning to the thinking of the nineteenth century Catalan jurists and by paying attention to their arguments on legal and political theory without attempting to reduce it to the social and economic controversies of the time which, although they help to understand - and even in some way condition nineteenth century Catalan legal theory, they in no way minimise or determine it.

In the following pages we attempt to demonstrate how, during the nineteenth century, the Catalan legal elite formulated a general legal theory whose starting point was an organic idea of society, and which pronounced a concept of authority (family) and freedom (not individualist) which would bestow the political liberalism project of Catalanism with a character of its own.

\section{THE HISTORICAL SCHOOL OF}

\section{LAW AND THE CATALAN LEGAL SCHOOL}

This defence of specific interests (and of the particular institutions of traditional historical law that regulated them) and this legal and political model that was being proposed in the middle of the nineteenth century in Catalonia was interpreted, of course, within the framework of the prevailing theses of the Catalan Historical School of law, such that after 1851 the defence of Catalan law would be interpreted as opposition to codification which was being orchestrated from Madrid for the whole of the Spanish State.

Eduardo de Hinojosa's opinion that Pedro José Pidal $^{62}$ was the first person in Spain to draw up a clear and convincing ideology for the Historical School has been much cited. It is also widely believed in Spanish legal historiography that the jurist who first made a name for the Historical School of Law was Eduardo de Hinojosa Naveros ${ }^{63}$.

However, for the Historical School of Law to truly come into being, to really come to life, a connection between the past and the future needed to be made. The basic assumption of the Historical School was that historians of law had a very important legislative task: to be the guide and li-

\footnotetext{
${ }^{62}$ Eduardo de HINOJOSA Y NAVEROS: 'Plan of a work of national jurisprudence of 1803', in Revista General de Jurisprudencia y Legislación, no. 13, 1958, pp. 39 et seq. This magazine, upon its creation (1853), became one of the points of entry of the Historical School in Spain.
}

Regarding Pidal and his diffusion of the Historical School, his opening speech in the Royal Academy of Jurisprudence and Legislation, of which he was president in 1843 , is usually mentioned, as is his 'Lessons about the government and legislation in Spain', read in the course he gave in the Cultural Centre of Madrid in 1841 and 1842

${ }^{63}$ Francisco TOMÁS Y VALIENTE: 'Eduardo de Hinojosa and the History of the Law in Spain' , in Anuario de Historia del Derecho Español, LXIII-LXIV, 1993-1994, pp. 1065-1088.

From 1878 onwards Hinojosa established relationships with key members of the German branch of the school and in 1883, when the Chairs of History of Law in the Spanish University were created, he published his Historia general del Derecho español, volume I, Madrid, 1887. The second volume was never published. The works of Hinojosa are very well known. Of particular interest here are those in which he applies the methodology of the Germanists of the Historical School to mediaeval Spanish sources. They can be looked up in the two-volume recompilation of his works collated by the National Institute of Political Studies, Madrid, 1948-1955, with an introductory study by Alfonso García Gallo. 
mits for legislators, to guide the process of reform in line with popular feeling that was defined and captured only in history. And this purpose, and even this intention to write history, was far removed from both Hinojosa's motives and those of his outstanding School, which was basically comprised of Claudio Sánchez Albornoz, José María Ramos Loscertales and Galo Sánchez Sánchez.

In Catalonia a law school with the ideology of the Historical School of Law was able to consolidate itself at a key moment, in the middle of the nineteenth century, when civil law in the Spanish state was in the process of being unified into a Civil Code of law. A group of Catalan jurists were able to merge into this ideology and demand that the codification process be temporarily put on hold to give them a chance to define, by means of an historical study of their institutions, their own legal framework so that this could, when the time came, be codified without threatening their national character.

The introduction of this law programme in Catalonia has some peculiar characteristics. Durán Bas referred to Reynals Rabassa and his work as chair of Roman law at the University of Barcelona: the works of Savigny had fallen 'prematurely into his hands (...) at a time when they were little known in Spain,'and from that moment onwards throughout his university career Reynals Rabassa strove, in the words of Durán, to 'teach Roman and general law with the theses of Savigny'64.

The predominance of the thinking of the Historical School of Law within the group from the so-called Catalan Legal School was, however, in no way absolute. Such an eminent member of the School as Martí de Eixalá was, for example, deeply imbued with the doctrine of Pothier and Scottish Common Sense Realism, and it must be remembered that many of the jurists of the Catalan School were his disciples at the University of Barcelona (Durán Bas and Permanyer, to name just two).

However, it is also true that as the second half of the nineteenth century progressed the historicist factor took on an increasingly important role in the thinking and programmes of this group of jurists. Perhaps the jurist who best symbolises this transition is Francesc Permanyer Tuyet; his speech to Congress on 7th January 1861 is often cited as illustrative. One of the things he declared in this speech was:

'The historical school in our Spain is not exclusively characterised by the inclination to preserve provincial powers; the historical school in Spain, as in other cultured and civilised countries, is also characterised by its tendency to conserve the existing legal law, by an aversion to its reform and modification where there is no imperious and therefore inescapable requirement to do so, by its inclination to restyle and reconstruct the law with, wherever possible, old elements, with elements already sanctioned by tradition, elements already consecrated by experience and embedded in the conscience and sentiment of the country which is, as we all know, the true and only fundamental source of established law'65.

This extolling of the Historical School of Law was due more to the impositions of the political logic of the time than to the Catalan jurists' doctrinal leanings, bearing in mind that the programme of the Historical School adapted

\footnotetext{
${ }^{64}$ Manuel DURÁN I BAS: Reynals i Rabassa. Estudio biográfico y literario, leído en la sesión pública que se celebró el 29 de mayo e 1883 en la Real Academia de Buenas Letras de esta ciudad, Barcelona, 1883, pp. 13 and 16.

${ }^{65}$ This citation of the speech is taken from DURÁN I BAS: 'The Catalan Legal School', p. 366.
} 
enormously well to the situation in Catalonia in relation to the codification project and the unification of civil law.

It is also certain that Permanyer's training was much more eclectic than his speech to Congress suggested. Through Martí de Eixalá he must have acquired a good knowledge of authors such as Thomas Reid (Scottish Common Sense Realism) and Balmes, and given the course of his political career and his standing and reputation as an intellectual and a man of his time, he partook of such wide-ranging thinking as the historical hypotheses of Stahl, the Krausist programme of Ahrens and the legal theory of Lerminier ${ }^{66}$. His programmes as chair certainly testify to this fact $^{67}$.

Another factor that nuances and questions the true importance of the Historical School in the Catalan Legal School was the limited first-hand access to the work of Savigny in Catalonia the middle of the nineteenth century.

In the 1840s it was almost impossible to find the works of Savigny in Castilian (with the exception, perhaps, of the translation of Tratado de la posesión: según los principios del Derecho Romano published in 1845 in Madrid). He could, however, be read in French because between 1840 and 1851 Traité de droit romain was published in Paris and some books reached Catalonia in this language.

What is certain is that for most prominent Catalan jurists, and for Spanish jurists in general, knowledge about the ideology of the Historical School of Law in the 1840s came, paradoxically, not from Savigny but from Lerminier ${ }^{68}$. This is not at all surprising considering that his work was well known and had even been presented to the General Administration of Studies to be approved for use as a text book in the law faculties ${ }^{69}$.

The translation of $M$. Eugène Lerminier's Introducción general a la Historia del Derecho was published in Barcelona in 1840. This was, indirectly, an enormously powerful source for the dissemination of the values and thinking of the Historical School, which had been very much sifted by the ideological approach of the author and which adapted perfectly to the Catholic tradition of $\mathrm{Ca}$ talan society.

The importance of Lerminier's work as a source of historicism in Catalonia, and in Spain in general, is quite surprising. A consultation of the doctoral theses read in the middle of the nineteenth century at the Central University of Barcelona, some of which were published in the Revista General de Legislación y Jurisprudencia ${ }^{70}$, attests to this.

${ }^{66}$ Further information about these authors and their place and influence in the politics of that era is provided later.

${ }^{67}$ Permanyer was a professor at the University of Barcelona from 1848 onwards, and in 1856 he was also Mayor of the city. He was a member of the Liberal Union and in 1862 he took charge of the Chair of Philosophy of Law in Madrid, where he became a member of the Cortes and rose to the position of Minister of Ultramar. The breadth and syncretism of his legal theory is evident in his programme of the Chair of Philosophy of Law, where the influence that the approaches of Stahl and Ahrens had on him are patently clear, and were reflected in the programmes of his classes both in Barcelona and in Madrid, cf. Manuel DURÁN I BAS: Noticia de la vida y escritos del Excmo. Sr. D. Francisco Permanyer y Tuyet, leída en la sesión pública celebrada por la Academia de Buenas Letras el 1 de junio de 1870, Barcelona, 1870, especially pp. 31, nos. 1 and $34, \mathrm{n} .1$.

${ }^{68}$ Antonio Álvarez Morales points out that even the figure usually accredited as being the first to introduce Savigny in España, Pedro-José Pidal, had no direct knowledge of the father of the Historical School; his indirect knowledge came through the work of Lerminier (and from the work of LEFEVRE DE LABOULAYE: Essai sur la vie et les ouvrages de F. C. de Savigny, París, 1842, as Pidal himself recognised in his aforementioned Speech in the Royal Academy of Jurisprudence and Legislation). Cf. Antonio ÁLVAREZ DE MORALES: Historia del derecho y de las instituciones españolas, Madrid, 1989, p. 53.

69 ÁLVAREZ DE MORALES: Op. cit.

${ }^{70}$ Examples are the work of RODRÍGUEZ MARTÍN Influencia de la Revolución Francesa en la codificación civil. De las cuestiones suscitadas en Alemania con este motivo. De los obstá- culos que retardan unificar la legislación civil española; and that of Fermín HERNÁNDEZ IGLESIAS Origen y fundamento y valor del Derecho consuetudinario. 
In the introduction to his work, Lerminier remembers his youthful boredom with the study of the extremely tedious codes of laws and how, coincidentally, a copy of De la vocación de nuestro tiempo para la legislación y la jurisprudencia (From the vocation of our time for legislation and jurisprudence) had fallen into his hands. 'I knew a little German and I started to read it,' he recalls, and goes on to describe the effect his reading had on him:

I could hardly contain my surprise: the author distinguished between law and laws. He spoke of law in an impassioned way, he treated it as something real, dramatic and full of life, and he ended by severely criticising legislation and the codes themselves $^{71}$

For jurists like Durán Bas, Permanyer and Reynals Rabassa the discovery of this book was a reaffirmation of their thinking: law was not the same as the laws. The laws promulgated in Madrid, the Civil Code, was something quite different from the law in Catalonia: thus, Catalan law began to see itself as an entity that was 'real, dramatic and full of life.'Lerminier's book had a clear objective:

Of what does this Introduction consist, then? What was my aim in writing it? It was to awaken the idea of law; to distinguish it entirely from legislation; to establish a theory of positive law that joins forces with philosophy and history at the heart of jurisprudence and demonstrates that law consist at once of the philosophical element and the historical element $t^{72}$

Lerminier was not a pure historian; he incorporated elements of Catholic ius naturalism into the programme of the Historical School. 'Human nature is the origin of law and where its base is found,' he affirmed. 'As the idea of law exists in the nature and conscience of man, this must manifest itself in history and develop itself within it with monumental energy ${ }^{73}$.' He continued:

(...) pure and absolute ideas of the conscience then take on the hint of passions and preoccupations, they are reduced to practice, they pass into history and they shake off the philosophical purity to take on a national character and garb. There is a time, then, when customs are the only thing that expresses the law of a people (...) and in the end, there comes a moment when youth disappears and with it the imagination; ideas need to be more precise, images are not enough any more, and law passes from being a symbol to being legislation. The law is recorded, customs are written down and what only existed in the memory of the peoples passes into the formulas of the legislative style. (...)

One must not, then, confuse the law with legislation. Legislation is the expression, the style of law, but it is not its substance ${ }^{74}$.

The law, defined as the manifestation of human nature, evolves and takes shape throughout history until the time comes when it acquires legislative expression. However, independently of what this 'expression' is, law means a' continuous practice' and 'the aim of a continuous practice must necessarily be reflected in the understanding of man; therefore, the theory is a consequence of the legislation, it comes after scholarly study'. This is the moment of legal writing, of doctrine, and this is where the role of Roman law fundamentally stood out.

\footnotetext{
${ }^{71}$ M. Eugène LERMINIER: Introducción general a la Historia del Derecho, Barcelona, 1840, p. 3.

72LERMINIER: Op. cit., p. 7 .

${ }^{73}$ LERMINIER: Op. cit., p. 16

${ }^{74}$ LERMINIER: Op. cit., p. 25.
} 
Legal writing is a consequence of legislation; it stamps the law with its seal and its logic; it establishes its principles, formulates its axioms, works out the consequences and through developing the idea of law endless conclusions are achieved (...)

Roman law has no equal in this sense: others can answer to some of its principles, but its method, its logic and its scientific system have made it and continue to make it superior to all other legislations ${ }^{75}$.

Lerminier thus developed a triangular concept of the law:' it exists in human conscience, in history and in science ${ }^{76}$.

This triangular concept fit perfectly into the thinking that originated at the Faculty of Law of the University of Cervera and was developed by the jurists of the Catalan Legal School, giving rise to a similar triangular concept of law which, parallel to that of Lerminier, was defined by Catholic traditionalism (human conscience) customary law (history) and Roman law (legal science).

From this three-dimensional perspective, Lerminier outlined a programme which attempted to include all aspects of the law.

The basic premise of the programme was that 'the first element that must be recognised in positive law is the philosophical element. Absolute ideas of what if fair and what it true constitute its base and its essence (...) These are the ideas that the human race has never stopped honouring and practicing in the name of natural law ${ }^{77}$,

This eternal base of absolute ideas, which is the same everywhere, takes on a thousand different forms wherever there is man (...); history has been associated with philosophy, at times to find its expression and at other times to mould it.

This fusion of philosophy and history has taken on an individual and distinct personality in each territory, which participates of both (...); such is positive law, an association of universal principles and national maxims $^{78}$.

The theory of law that can be inferred from Lerminier's work is at once historicist and ius naturalist, which meant that the model of the Historical School of Law was acceptable to a Catholic and conservative social milieu as was the Catalan bourgeoisie and aristocracy in the middle of the nineteenth century.

Leminier, in taking into account the importance of the philosophical element to a real understanding of the law, was in no way an ius rationalist. He spurned learned reformers whose only criterion was reason: 'In effect, you only take the philosophical element and you mutilate scientific scholarly studies: you move to and fro between theories (...). All that is true, national, political will be hidden from you ${ }^{79}$.

'If, on the other hand, only the historical element grabs your attention; if in law you only take the national into account, you disregard what breathes life into all institutions, the rational, the absolute (...). And so, the celebrated leader of the German Historical School, M. De Savigny, who is occupied only

\footnotetext{
${ }^{75}$ LERMINIER: Op. cit., p. 33.

76 LERMINIER: Op. cit., p. 36.

77LERMINIER: Op. cit., p. 36.

${ }^{78}$ LERMINIER: Op. cit., p. 36-37.

${ }^{79}$ LERMINIER: Op. cit., p. 38.
}

Spanish Journal of Legislative Studies, Núm. 1, 2, pp. 1-40. 
with history, with what is individual about the law of nations, with their customs, with their political instinct, has not known the philosophical basis of positive law, the human and universal element ${ }^{80}$.

The last proposal that Lerminier made was enthusiastically taken up by the group of Catalan jurists that we have been discussing:

The attorney-at-law, in the reforms he resolves to carry out in our days, by means of his dual knowledge of philosophy and history, will manage to save himself from both an unintelligent routine and an ignorant and explosive radicalism ${ }^{81}$.

Thus was the nature of Catalan legal historicism - a traditionalist, Catholic, conservative historicism which, logically, could not exist outside of ius naturalism but needed to brandish historical traditions in self defence against certain reformist urges that threatened in the guise of the codification of civil law.

In spite of the nuances of this historicism, which we could call Catholic, the influence of the theses of Savigny in Spain in relation to the pure programme of the Historical School of Law was significant. Pedro Gómez de la Serna even affirmed that at the end of the reign of Elizabeth II that the diffusion of the theories of the 'Historical School of Law' in Spain would cause codification of civil law to be observed 'with mistrust', whereas 'some years before it had seemed natural, simple and no cause for great inconvenience ${ }^{82}$.

\footnotetext{
${ }^{80}$ LERMINIER: Op. cit., p. 39.
}

It also made reference to those that had as the only element of understanding about law their character as legal writing: 'Finally, if we forget everything philosophical and historical about positive law, we concentrate only on the intelligence of the formulas and the tests, only on the dogmatic or geometric shape, we can deduce exact consequences, showing us logical things but nothing else', ibidem, p. 40.

${ }^{81}$ LERMINIER: Op. cit., p. 335.

${ }^{82}$ Pedro GÓMEZ DE LA SERNA: 'Codification at the end of the reign of Elizabeth II', in Revista General de Legislación y Jurisprudencia, volume 39, p. 297
And it was in Catalonia that this influence was greatest. In fact, Barcelona was the only Spanish city where the Savigny Foundation had a Committee; it was established there by the College of Lawyers in 1869 with Manuel Durán Bas as its president.

\section{THE CATALAN LEGAL SCHOOL WITHIN THE POLITICAL FRA- MEWORK OF SPAIN IN THE SE- COND HALF OF THE NINETEEN- TH CENTURY}

If there was a landmark moment that reveals the profiles of the ideologies that were pressing for change in the failing Spain of the middle of the nineteenth century then it was the revolution of 1868.

For the first time in Spain there was a bourgeois revolution that was entirely without hint of commitment to the Old Regime: For the first time in Spain there was widespread call for a fully liberal monarchical parliamentary regime, or what was then referred to as a 'democratic monarchy'. It has often been said that it was a revolution of the middle classes, of small and medium-sized businessmen, of shopkeepers and craftsmen. In this revolutionary setting three currents that all originated from the bourgeoisie and their reformist pretensions can be seen: the krautists, the Catholic liberals and the supporters of Catalan autonomy ${ }^{83}$. 
The way these three groups have usually been portrayed is: First, there was profound criticism of the political, social and economic situation of the time, which was determined by the programme supported by Cánovas del Castillo, the so-called 'Restoration': Second, having found the current situation untenable, some of the theoretical projects that emerged at that time (which would never actually be carried out) were analysed, giving rise to a thorough study which extolled the virtues of some of these projects, which would never actually be corroborated, and which would later be portrayed as great but lost opportunities.

The influential works of professor Gil Cremades $^{84}$ on this matter came to the conclusion that the krausists, the Catholic liberals and the supporters of Catalan autonomy were among the few political programmes of the time that gave a liberal democratic project in Spain theoretical substance and a chance of success. The outcome was inevitable: as their proposals got thrown into disarray so Spanish political powers could no longer count on the support of a bourgeoisie with 'centrist'85sympathies, but would find themselves drawn into confrontation between extremists, which would inevitably lead to the civil war of 1936.

This is the framework from within which the importance of the failure of Catalanism in nineteenth century Spain has been understood: as part of the failure of a project of 'centrist' liberalism, which led Spain into a devastating situation.

We consider that inherent within the aforementioned interpretative framework of that historical period are some obvious methodological problems. Comparing the actual (and always in some way deficient) situation with unblemished theoretical projects inevitably creates myths and prejudices around ideologies, programmes and figures; myths and prejudices which, over time, weigh heavy on the social conscience making a much needed sober, open-minded analysis difficult.

Of the three fruitless projects left by nineteenth century Spanish liberalism the one we investigate in further depth here is the so-called 'Catalanist' one, which was perhaps the least futile of the three. We focus on one particular aspect of this project, the legal aspect, because without doubt part of the programme of those who supported Catalan autonomy was represented by the Catalan Legal School ${ }^{86}$.

${ }^{83}$ From the middle of the nineteenth century onwards the University of Barcelona was the great driving force of the Catalan bourgeoisie. More specifically, between 1847 and 1857 what came to be known as the first 'hornada' (literally 'batch') of jurists that were fully aware of their belonging to the true Catalan bourgeoisie was formed. This circle was basically made up of the set of jurists that Duran groups into what was called the Catalan Legal School.

84 Cf. Juan José GIL CREMADES: El reformismo español: krausismo, escuela histórica, neoto- mismo, Barcelona, 1969; también, Krausistas y liberales, Madrid, 1975.

${ }^{85}$ In that era 'centre' must be understood to mean the political position that was equidistant between individualist liberalism and the aristocratic positions that inclined towards maintaining the privileges of the Old Regime and the revolutionary postulates of a socialist nature. Certainly, Spanish political life in the XIX was always propelled by one of three postulates: socialism, liberalism and moderantism. Neither the projects of krausism, nor those of the Catholic liberals or of Catalanism, managed to take enough hold in Spanish society to constitute viable political alternatives (for reasons that go beyond the scope of this paper).

${ }^{86}$ Political Catalanism had an essential legal component, and not only because of the need to oppose the codification process that was being orchestrated from Madrid. Awareness of the fact that the Civil Code had enormous potential to create a single national space meant that opposition to Spanish civil codification was a foregone conclusion. Apart from this, we must also remember that together with the Catalan language, Catalan law was considered to be one of the two pillars of the nation. In this regard, Valentí ALMIRALLi's article: 'Address in defence of the civil law of Catalonia', Diari Català, 30th January 1881; the publication by Lluis Maria de Llauder in El Correo Catalán of 3rd January 1881, entitled ' Catalan civil law'; and the article 'The first victory of Catalanism' by Narcís Verdaguer, published in the newspaper of the town of Vic, La Veu de Montserrat, in August 1889. 
What is needed, therefore, is an examination of the nature of Catalanism within the Catalan legal culture of the second half of the nineteenth century $^{87}$ and this from a position of awareness of the fundamental importance of the part played by the legal elite in the European political processes of the nineteenth century 88 .

One extremely interesting jurist who helps to define the political stance of the jurists of the Catalan Legal School within the framework of bourgeoisie reformism in the second half of the nineteenth century is Ramon Martí d'Eixalà, and this despite his early death in 1857 at the age of 49 . From his position as Chair of Law at the University of Barcelona, to which he was appointed in 1848, he became the maestro of almost all of the weII-known jurists of the group of 1847.

Martí d'Eixalà's importance to an understanding of the essence of legal Catalanism within the bourgeoisie reformists' general project in Spain in the second half of the nineteenth century starts to become evident if we delve further into his condition as professor of 'ideology' at the Academy of
Natural Science of Barcelona, a period of his life usually given little importance.

Attention to Eixalà usually centres on his work as a jurist, but his true passion was philosophy. He was profoundly imbued with the ideas associated with Scottish Common Sense Realism, or the Scottish School of Common Sense. In his book Course on Elementary Philosophy, which was published in Barcelona in 1845 89 , we find from his reception of the thesis of Thomas Reid the weII-worked expression of something quintessentiaIly Catalan, 'seny' ${ }^{90}$ or 'practical sense', introduced as the hallmark of the Catalan character or spirit.

For the Scottish theologian Thomas Reid, whose long life spanned almost the whole of the eighteenth century, the consequence of the traditional doctrine of the ideas of British empiricism (expounded by Berkeley, or in Hume's version) is the 'dissolution' of the world because, as classical empiricism maintained, if all of reality is broken down into a set of basic units which are 'impressions', also called 'simple ideas', the inevitable consequence is to consider the individual as a

${ }^{87}$ In this regard, the unpublished thesis of Albert GARCI I BALASAÑ̀̀: Ordre jurídic liberal i trajectòria de l'Acadèmia de Jurisprudència i Legislació de Barcelona, 1840-1931 (A propòsit de la formació i els límits de la política burgesa a Catalunya), Autonoma University of Barcelona, 1993.

The studies of institutions central to Catalan legal and political life of the XIX century are of enormous interest on this point. Cf., in this regard, Enric JARDí: Història del Col-legi d'Advocats de Barcelona, 2 vols., Barcelona, 1989. Laureà PAGAROLAS I SABATÉ: Història de I'Academia de Jurisprudència i Legislació de Catalunya, Barcelona, 2000. Jordi CASASSAS YMBERT: L'Ateneu Barcelonès: Dels seus orígens als nostres dies, Barcelona, 1986.

${ }^{88}$ Cf. Terence C. HALLIDAY y Lucien KARPIK: 'Politics Matter: A Comparative Theory of Lawyers in the Making of Political Liberalism', in Lawyers and the Rise of Western Political Liberalism: Europe and North America from the Eighteenth to Twentieth Centuries, Oxford, 1997. Richard L. ABEL y Philip S. C. LEWIS (eds.): Lawyers in Society, vol. 2, The Civil Law World, Berkeley, 1988.

${ }^{89}$ This is the edition that I have used, even though there is a previous one: Curso de filosofía elemental comprendiendo la teoría de las ideas, la gramática general y la lógica, Barcelona, 1841.

${ }^{90}$ Francesc CAMBÓ's stance in Por la Concordia, Madrid (1927) is usually used as a political example of seny. Cf. the influence of the Scottish School of Common Sense and the traditional Catalan political attitude in the work of Josep LLOBERA: 'The formation of Catalan nationalist ideology. The idea of Volkgeist as a defining element', in L'Avenç, no. 63, Septembre 1983, pp. 24-35. Also: Norbert BILBENY: La ideologia nacionalista a Catalunya, Barcelona, 1988, pp. 99-107. Lastly, Stephen JACOBSON: 'Law and Nationalism in Nineteenth-Century Europe: The Case of Catalonia in Comparative Perspective', in Law and History Review, vol. 20, no. 2, 2002. I have consulted the digital version of the article. The citation corresponds to paragraph 45: http:/l www.historycooperative.org/journals/lhr/20.2/forum jacobson.html. 
mere 'receptor' deprived of his own reality, which only the simple ideas have.

Upon this the Scottish School imposed the concept of judgement that started from the precept that all ideas are the outcome of a set of 'primary' and natural judgements that reside within the human being ('common sense'), from which (and not the other way round) ideas are formulated. Ideas, therefore, do not give judgement consistency; judgement generates ideas, understanding - perceiving - impressions, and believing in their actual existence outside the self. From this point of view, the doctrine of common sense not only did not dissolve the world, but it actually settled and secured it.

It was, as we can see, a statement about the individual which was equidistant between traditional British empiricism and German idealism. Jaume Balmes, influenced of course by Martí d'Eixalà, played a principle role in this profoundly Catalan methodology and line of thought, and Eixalà's followers would be educated in these principles.

One of the most important of these followers was Francesc de Permanyer. He developed and enhanced the initial proposals of his maestro Eixalà with the aforementioned philosophical currents that were swirling around the krausist and Catholic liberalist circles.

Reynals Rabassa ${ }^{91}$ was another of Eixalà's important followers. He investigated in further depth this theoretical line of thought around the School of Common Sense Realism, managing to find 'internal harmony with the Historical School of Law', such as in the fleeing from all abstraction in relation to the law and the valuation of practical and inductive procedures ${ }^{92}$.

Historical theorists like Lerminier and Friedrich Julius Stahl managed to wield great influence in this philosophical breeding ground. Ultimately, it was about systems which contributed criteria against rationalism and the current of natural law. The superiority of positive law contained within the historical institutions was proclaimed above the rationalist natural law of radical liberalism; traditional experience as opposed to idealism.

Spanish krausism was perfectly compatible with these lines of thought, not because strictly and speculatively it was this way, but because Spanish krausism ended up being first and foremost 'a way of life'93 rather than a philosophical system, and this way of life was represented by the highest echelons of the reformist bourgeoisie in Spain in the political arena and in the sphere of the philosophy of law. Thus, it is perfectly valid to say that Catalanism was far removed from the project of spiritual renovation that the Free Institution of Teaching came to represent in the field of education, or that men of such standing and significance as Gumersindo de Azcárate came to represent in the legal field.

This explains why Prat de la Riva himself stressed how important the systems very close to krausism, like the romantic theory of Herder ${ }^{94}$ and Schelling's ${ }^{95}$ organicism, were for his group, and this without having to renounce the legal historicism of Savigny. In his own words:

\footnotetext{
${ }^{91}$ Cf. Manuel DURÁN I BAS: Reynals i Rabassa. Estudio biográfico y literario leído en la se- sión pública que celebró el 29 de mayo de 1833, en la Real Academia de Buenas Letras de esta ciudad, Barcelona, 1833.

92 Opus cit., p. 19.

93J. LÓPEZ MORILLAS: El krausismo español, Madrid, 1956, p. 212.

${ }^{94}$ Herder affirms the existence of a national spirit linked to the language and whose development is found in the history of each country, while the creations of the people and the great poets constitute a manifestation of this spirit, especially in the Christian Middle Ages.
} 
The Catalan Legal School is born of the confluence and the harmonisation of three elements: the ethic, contributed by the deeply Christian convictions of these law specialists; Scottish philosophy, with its method of observation and its analytical procedure; and the historical school of the German Romanists ${ }^{96}$.

In any case, legal Catalanism had an important point in common with krausism: criticism of individualism. In fact, Manuel Durán Bas's doctoral thesis 'Individualism and the Law', read in Barcelona in 1852, contained a comprehensive programme for legal Catalanism which included the idea that liberal individualism should be nuanced through the principles of authority and of association, which found expression in a very specific family law and patrimony.

In the face of rationalist individualism, the Catalan Legal School introduced a Catalan law distinguished 'by a solidly organic mechanism and mesh of social ties', which was firmly grounded in a profoundly traditional type of family and an organisation of real estate law that orchestrated different ways for 'all social classes to access property' by means of the emphyteusis and tenurial agreements such as the rabassa morta ${ }^{97}$.

All of this was, perhaps, the Catalan Legal School's greatest contribution to political Catalanism, so that as the twentieth century progressed this movement was able to rely on some very solid ideological bases which, although this is rarely revindicated, originated in the Catalan legal elite of the nineteenth century. How could the weII-known words of Francesc Cambó be understood if this was not so?:

The French Revolution destroyed all of the organic life of the villages; all the organic structures of life that had been created over the centuries were swept away by the gale of the French Revolution; regional and municipal, corporative and professional organisations fell; only the omnipotent State remained, and the self-determining man was left without any means or weapons to make his sovereignty felt ${ }^{98}$.

\section{OVERCOMING INDIVIDUALISM AND THE CONCEPT OF FREEDOM IN THE CATALAN LEGAL SCHOOL}

Many of the jurists of the influential Catalan Legal School were of the opinion that Catalan civil legislation was 'the richest in the world in civil liberty' ${ }^{\prime 99}$.

The secular civil freedom of this territory makes the Catalan people 'naturally inclined to disregard the State in their search for moulds and forms to serve as models for the means used to satisfy their socio-legal requirements, and to look for them instead in the legislative power of the people'100.

This idea of freedom, presented as essential

\footnotetext{
${ }^{95}$ Which would lead Catalanism to interpret the region or the province in an organic sense in relation to the rest of the Spanish state: with its own personality and autonomy, but connected to it by certain essential links.

96 Enrique PRAT DE LA RIBA: 'Durán i Bas', i Revista Jurídica de Cataluña, 18, 1912, p. 87.

97 Juan de Dios TRíAS: Conferencias de Derecho Civil Catalán, Barcelona, 1899, pp. 28-32.

98 Conference held in the Catalan Centre on 10th April 1920. The citation is taken from the book of Jesús PABÓN Cambó, 1876-1947, Barcelona, 1999, p. 49

99 FALGUERA: Conferencias de Derecho catalán dadas en el Ateneo Barcelonés, p. 13.
} 
to Catalan law and therefore, by extension, to the Catalan people, was interpreted at that time not from an individualist perspective, but from an 'organicist' one.

Of course, 'upon the arrival of the Restoration the legal mentality was fully impregnated with organicism'. Krausists, historicists and Catholics all agreed that the law had to have ' a harmonious, organic meaning, more closely tied to the communal, to life, than to the individual' ${ }^{101}$.

According to Juan de Dios Trías, 'Catalan law is also characterised by a solidly organic mesh of ties and cogs'. He saw this as a virtue, adding that 'nations in which individuals amass huge amounts of energy are those wherein the individual does not look for support in the grace of power but in the social organisation that he himself has cons- tructed'102. $^{\prime 10}$.

The members of the Catalan Legal School, the Catholics as well as the historicists, interpreted freedom as the free expression of society; and so Félix María de Falguera asked for 'liberties placed in their rightful position'. Firstly, freedom was represented by the basic unit of this society: the family.

Falguera affirmed that the principle of freedom of the family brought about three concepts in Catalan law: 'First, the authority of the head of the family; Second, the potential freedom of the individuals in harmony with the authority of the head of the family and without diminishing the unit, from which comes the emancipation of women according to their interests; Third, the independence of the family from legal power in everything that is

${ }^{100}$ Federico PUIG SAMPER I DE MAYNAR: 'The heiress', in Revista General de Legislación y Jurisprudencia, núm. 85, 1894, 2.o sem., p. 126.

101 Juan José GIL CREMADES: El Reformismo español, krausismo, escuela histórica, neotomismo, Barcelona, 1969, pp. 3 and 125

According to the krausists, doctrinairism 'lacks an essential, ethical, internal base' (Francisco GINER DE LOS RíOS: 'Old politics and new politics', in Estudios jurídicos y políticos, Madrid, 1875, p. 67); it has not been able to discover a national society, that human, organic unit that pursues an ideal that can only be achieved through social interaction (K. Ch. F. KRAUSE: Ideal de la Humanidad para la vida, introduction by Julián Sanz del Río, Madrid, 1860, p. 35) and which is organised through the law; the system of reciprocal and mutually claimable conditions that condition individuals in their aspiring to the human ideal.

According to the krausists, God is the organism of all beings. As such his supremacy is not conditioned, but at its core it integrates all of the conditions that connect life to individuals. Each of these beings, who are individual and finite, are triply conditioned by themselves, by their fellow beings through their inevitable coexistence, and by our Creator.

The conditionality of man is the law, and this has the peculiarity of being a free conditionality; Krause defines it thus: 'the freedom of life is conditioned by the end of life', KRAUSE: Ideal de la Humanidad, p. 191. In general, a summary of the krausist thesis on law and the state in GIL CREMADES: El Reformismo español, pp. 54-58.

The Historical School was another of the 'organisist' positions that coincided in the regime of the Restoration. The 'spirit of the people' constituted a chance to overcome dispersion and leads us to individualism and, in the face of doctrinairism, managed to bestow law with a real, vital, not merely rational, theoretical and also arbitrary base. (In this regard, Pedro José PIDAL: 'Inaugural speech', in Acta de la Sesión inaugural de la Academia Matritense de Jurisprudencia y Legislación, Madrid, 1843, p. 54). Within the Catholic movement it was the neothomists who best adapted to the new times. From this group we can highlight the cardinal Ceferino González Díaz-Tuñón, inspirer of the Catholic Union, and Alejandro Pidal y Mon, political implementer of the programme of the cardinal González. The characters Juan Manuel Ortí y Lara, Nicolás María Serrano, José Pou y Ordinas and Pedro López Sánchez were also important. These reaffirm the principle of the social condition that demanded, in their opinion, a principle of authority. More precise, the organism of society would be supported by its hierarchical order.

The law, for the neothomists, was something indivisible from the social body; and just as separation was impossible, there would be epistemology between soul and body and between form and matter; neither would there be separation between moral and right. A right, which in the last instance, came from God. These matters are explained in further depth in GIL CREMADES: El reformismo español, pp. 155-180.

${ }^{102}$ Juan de Dios TRÍAS: Conferencias de Derecho civil catalán, Barcelona, 1899, pp. 28-29.

Spanish Journal of Legislative Studies, Núm. 1, 2, pp. 1-40. 
not contentious'103.

The reference point for this concept of freedom, which was expressed socially from the family, was a particular type of property law from which all civil law in Catalonia radiated. This is why, according to Durán Bas, an incomplete concept of property law is formulated from 'reducing property, within the general organism of private law, to being the highest synthesis of the law of things, independently of that of the obligations that form part of it, and of that of the successions which, as Savigny said, far from being inferior to it, coordinate with it' ${ }^{\prime 104}$.

'Catalonia has become enriched before the rest of Spain thanks to free work (...), to the work of man more than to what the natural environment has provided. Two sentiments, which appear to be opposed but are in fact harmonious, have simultaneously been born of this: that of the freedom to dispose of assets and that of preserving the patrimony that has been amassed. Work amasses patrimony and it is safeguarded by adhering it to the family. Without freedom of contract, to dispose inter vivos, the motivation to work wains; without the freedom to command in your last will and testament the destiny of one's assets the fruit of a long and industrious life can disappear; and if throughout his life a man works for his wife and his children, when he dies, he disposes of his assets in the way that is of greatest benefit to them according to their situation. If these two concepts - the family unit and the preservation of its patrimony - are eliminated from Catalan legislation; if the two principles - freedom of contract and testamentary freedom - are eliminated, and in so doing this legislation in the spirit that it was conceived is destroyed, then two things will necessarily disappear: the moral physiognomy of Catalonia and the wealth which, shared out without great inequalities of fortune, is the reward for industriousness and good habits ${ }^{105}$

Freedom of contract, 'to dispose inter vivos' is the best way to motivate people to work hard and to amass property. However, it is a specific family system, one of the essential components of which is testamentary freedom, that ensures that the patrimony is preserved. We see, then, how the idea of 'freedom' was perfectly incorporated into a system of property ownership (freedom to dispose, both inter vivos and mortis causa) and

${ }^{103}$ FALGUERA, ibidem, p. 13. The family wasconstructed within the central link of the social organ, which was placed in relation to the other two basic structures: the individual and the municipality. In a similar vein, but from ius naturalist positions, Torras y Bages affirmed that the family, municipality and region constituted the organic structure of society, and in this sense Catalan law gave this region its particular form. We find ourselves at the end of the XIX century, still too early to predict how a concept of nationalist democracy that was enlightened by this idea of liberty would degenerate., but the consequences for other parts of Europe need no explanation.

104 Memoria acerca de las instituciones del Derecho civil de Cataluña, Barcelona, 1883. I cite from the facsimile edition published in the Collection of Catalan Legal Texts, t. 10, Projecte d'Apèndix i Materials Precompilatoris del Dret Civil de Catalunya, p. 104.

105/ bidem, pp. XCIII-XCIV.

106 The influential work of the Mercedarian friar MAGÍN FERRER: Las leyes fundamentales de la Monarquía española, según fueron antiguamente y según conviene que sean en la época actual, published in Barcelona in 1843, is illustrative of the profiles of Catalan legal traditionalism. In this work a concept of pluralism that is understood from an exclusively social point of view is brought to light, not in its political sense, but conceiving of society as an autonomous entity organised according to the criteria of natural law, while its rights are the expression of its liberties.

${ }^{107}$ DURÁN I BAS: Memoria, p. XCIV.

Spanish Journal of Legislative Studies, Núm. 1, 2, pp. 1-40. 
into a specific family system.

These basic and defining concepts of the historical Catalan legal system expressed an idea of freedom that was characteristic of traditionalism ${ }^{106}$ and so was armed with the following principles ${ }^{107}$ : First, 'respect for paternal authority'; Second, 'the concept of the family as a unit, not something transitory, but something that perpetuated through intergenerational links'; Third, 'the dignity of the widowed mother'; Fourth, 'personal responsibility'; Fifth, 'free activity as the condition of all human action in relation to assets'; Sixth, the law 'limited to the requirements of order and peace in social relations'.

This set of ideas was perfectly assimilated into the Catalan social conscience, was 'more intuitive than reflexive; but firmly rooted in the conscience, influential as criteria, and characteristic to construct the moral identity of the Catalan nation'.

We will comment briefly on each of these principles.

\section{1. 'Respect for paternal authority'}

For legal Catalanism social freedom takes its meaning through the father of the family exercising this very freedom. The subject of freedom, therefore, is not the individual but the father of the family and this freedom resides in his paternal authority. It was only because all authority was bestowed upon him that the father could act with freedom.

Paternal authority, therefore, was at the heart of Catalan family law which, ultimately, was Roman law ${ }^{108}$. The result was a patriarchal style family in which the father exclusively assumed all matrimonial duties ${ }^{109}$ and parental rights ${ }^{110}$. Children were only released from this parental authority through marriage (in that they constituted a new family), emancipation or the priesthood.

The immediate consequence of the exclusively paternal exercise of parental rights was that the father had total control of the entire family patrimony, including his offspring's money even if they had reached the age of majority, given that this in itself did not automatically mean emancipation ${ }^{111}$.

Adulthood, according to the rules established in the Usages ${ }^{112}$, was interpreted to be twenty years of age. The Usages established the principle that 'commoners recover their honours and fur-

${ }^{108}$ Guillermo M.a de BROCÁ: Historia del Derecho de Cataluña, especialmente del civil y ex- posición de las instituciones del Derecho civil del mismo territorio en relación con el Código civil de España y la jurisprudencia, Barcelona, 1918, p. 656. 109Cf. Joan PERE FONTANELLA: De pactis nuctialibus sive capitulis matrimonialibus tractatus etc., Gerona, 1638, clause 6, annotation 1.a, part I, no. 63; clause 6, annotation 2.a, part III, no. 8. Tomás MIERES: Apparatus super Constitutionibus Curiarum generalium Cathaloniae, Barcelona, 1533, collation 4.a, ch. 12, no. 11.

${ }^{110}$ Lluis de PEGUERA: Decissiones aureae in actu practico frecuentes ex variis Sacri Regii Concilii Cathaloniae conclussionibus collectae, Barcelona, 1605, ch. 97, nos. 3, 4 y 5. FONTANELLA: De pactis nuctialibus tractatus, cláusula 5, glosa 8.a, part XI, no. 30. Tomás MIERES: Apparatus super Constitutionibus Curiarum generalium Cathaloniae, collation 9.a, ch. 12, no. 29. Jaume CÁNCER: Variarum resolutionum juris caesarei, Pontificii et municipalis Principatus Cathaloniae, Barcelona, 1594-1598, part III, ch. 1, no. 214.

\footnotetext{
${ }^{111}$ As already stated, in Catalonia age in itself did not terminate parental power; this only concluded through emancipation, by entering the church or by marriage with the father's consent. Cf. FONTANELLA: De pactis nuctialibus sive capitulis matrimonialibus tractatu etc, clause 4, annotation 2.a, no. 38; MIERES: Apparatus super Constitutionibus Curiarum generalium Cathaloniae, collation 6.a, 'De emancipatione et foriscasatione', no. 29; collation 9.a, ch. 12, no. 29; CÁNCER: Variarum resolutionum juris caesarei, Pontificii et municipalis Principatus Cathaloniae, part III, ch. 1, no. 214.

In Catalonia, the Roman tradition of the grandchild being under the parental power of the grandfather survived until 1351 , after which it was established that marriage, with the father's consent, brought about emancipation.: CYADC-1704, I, VIII, 8, 1.a

${ }^{112}$ CYADC-1704, I, V, 4, 1.a.
}

Spanish Journal of Legislative Studies, Núm. 1, 2, pp. 1-40. 
niture from their guardian at the age of 15 years', whilst for nobles the principle was that they could litigate for themselves from 20 years old. After contemporary repeal of the stratified society most people considered 20 to be the age of majority in Catalonia (even though the restitution in integrum was not reached until 25) ${ }^{113}$.

However, as reaching the age of majority did not necessarily mean emancipation neither did it imply any change in the patrimonial order of the family given that the father maintained the beneficial ownership, or usufruct, of his offspring's peculium adventicium (property acquired by a son or daughter through the exercise of a profession, or through art, industry or fortune, as well as inherited property) and the property of the profecticio (property acquired with that of the father or property derived from the father). Generally, a child could not enter into contract without paternal consent, nor could he go to trial without being represented by his father, as his father was the legitimate administrator of all of his assets ${ }^{114}$.

Thus, the entire patrimony was kept within a family structure which was represented in a rigid and absolutist way by the paterfamilias.

Catalan custom, though, was becoming less rigid in order to adapt to contemporary life, so that a son who was single but was engaged publicly and consistently in a commercial activity in the same way and with the same ability as would the father of a family was considered to have acquired the capacity to enter into contracts without his ac- tions needing to be validated by his father ${ }^{115}$.

Félix María de Falguera himself sought 'more rights for sons regarding the peculio adventicio and the profecticio, particularly over the latter for a son who does not live with his father and lives by his own means. This modification of Roman law, which is admitted in all modern Codes, must have been adopted (so said Falguera) by our ancestors before anybody else because it satisfies their basic principle of increasing the freedom of the individuals in the family, as long as the principle of authority is not compromised, and as long as this authority is not lessened when the son to whom these rights have been conceded forms a separate household thus becoming, even though he is single, the head of a family ${ }^{116}$.

\section{The family as a permanent structure able to perpetuate over time.}

In the words of Juan de Dios Trías:

Catalunya understood that the family is the main nucleus of all social organisation, and as society needs stability and roots, in Catalonia this main nucleus was bestowed with these two conditions. The family is not an established community whose only purpose is to constitute and form a generation and then dissolve when that generation passes puberty. The family is a bond that perpetuates over time ${ }^{117}$.

This principle was maintained through the law

${ }^{113}$ Segismundo MORET y Luis SILVELA: La familia foral y la familia castellana, Madrid, 1863, p. 26.

${ }^{114}$ FONTANELLA: De pactis nuctialibus sive capitulis matrimonialibus tractatus etc., clause 4 , annotation 7.a, part III, nos. 7, 10 and 14 .

${ }^{115}$ FONTANELLA: De pactis nuctialibus sive capitulis matrimonialibus tractatus etc., clause 4, annotation 7.a, part III, nos. 55 and 56. Maspons i Anglasell certify this custom in his jurisprudential reception. Cf. Nostre Dret Familiar segons els autors clásichs y les sentencies del antich suprem Tribunal de Catalunya, Barcelona, 1907, p. 96, no. 193.

${ }^{116}$ FALGUERA: Conferencias etc., p. 31. 
of successions. The Catalan law of successions required that for a will to be valid it had to include the institution of the heir, which went hand in hand with the principle of universality of succession.

Therefore, if a will was made a decision which necessarily affected all of the patrimony of the testator had to be made. And bearing in mind that the one who was in a position to dispose was none other than the father of the family, in Catalonia the will became a tool to maintain and preserve the whole family structure just as it had been shaped from the authority of the paterfamilias.

We have talked about the Catalan law of successions, but if we turn our attention to the Constitutions recompiled in Catalonia nowhere do we find the principle of the need for the institution of the heir. This principle came directly from Roman law and had been incorporated into Catalan law through the Reception, appearing in the notarial formularies of the Middle Ages ${ }^{118}$, incorporated through doctrine ${ }^{119}$ and applied through the jurisprudence of the Royal Audience.

In Catalonia, however, this Roman tradition took on its own colour. Throughout the Middle Ages, as it was adjusted to the needs of the times and adapted to feudalism, it took on the idea of primogeniture ${ }^{120}$, which gave rise to the figure of the heir. It must be said, however, that the principle of testamentary freedom, which is also a basic tenet in the Catalan law of successions, defined the shaping of the Catalan institution of the heir, the principle of primogeniture, which was more a custom than a necessity.

Usually, then, inheritance was defined by the figure of an heir, and while this meant that the other siblings were excluded from the family patrimony, which in itself was not ideal, it did ensure the greater good of the preservation of the patrimonial order of the family ${ }^{121}$. A paragraph from Moragas's well-known text explains this concept very well:

In vain they will look for those who are not used to our customs, in the majority of cases, this proliferation of Curials to make inventories, to value and share out the rich and poor accounts; in vain these terribly sad, for us merciless, auctions where appears the instrument that moves a familiar hand, or the office, witness to deep lucubrations, which form the aureole of our name, or the armchair from which our father gave advice, respected and followed by different generations, and the crosses which were a bell of unfading glory. The Catalan family today looks the same as yesterday; he who rests in eternity may think that he left for just a short

${ }^{117}$ Juan de Dios TRíAS: Conferencias de Derecho civil catalán, Barcelona, 1899, p. 29.

${ }^{118}$ This from the inexcusable Rolandino de PASSAGGIERI: Summa artis notariae, who deals with the testamentary question in his book III, to the influential works of Catalan notaries like GALÍ: Opera Artis Notariae, 1674, and José COMES: Viridarium artis notariatus sive tabelliorum viretum, published in two volumes in Girona in 1704 and 1706 (to mention only two of the many that are in circulation during the modern age).

${ }^{119}$ Cf. J. CÁNCER: Variarum resolutionum luris Caesarei, Pontificii et Municipalis Principatus Cathalauniae, Barcelona, 1670, Pars Prima, chapter IV, fragment 55, p. 87; J.P. FONTANELLA: Decisiones Sacri Regii Senatus Cathaloniae, 2 vols., 1668.

${ }^{120} \mathrm{Cf}$. I. TERRADAS SABORIT: 'The origins of the Institution of the heir in Catalona. Towards a contextual interpretation,' in Quaderns de l'institut catalá antropologia, no. 1, May, Barcelona, 1980.

${ }^{121}$ An heir becomes the favoured one, and if at first the exclusion of the legitimate heirs in the distribution of the inheritance may seem repellent, it must be borne in mind that this distribution would have broken up the family; they suffer discomfort, but the family perpetuates for future generations. At the same time, the heir is not free either, he holds a trusteeship, he suffers discomfort, but this discomfort also permits the perpetuation of the family patrimony', Juan de Dios TRíAS, Conferencias de Derecho civil catalán, p. 29. 
journey ${ }^{122}$.

In the authoritative opinion of Joan Martí Miralles 'the heir, according to Roman and Catalan law, is the universal successor of all the property and all the rights of the deceased. It is also he who succeeds the testator in all of his duties. The heir takes the place and the situation of the testator ${ }^{123}$.

The institution of the heir and the principle of universality of inheritance were needed

to be able to perpetuate the family order. For the same reason, Catalan law also assumed the regulation, which came from Roman law, that testate succession and intestate succession were incompatible. 'So within this principle of universality, the coexistence of two universal heirs in solidum is inconceivable, as is the coexistence even if just in part of an heir of one type of succession with an heir of the other type of succession, because then neither of the heirs would be the universal successor of the deceased ${ }^{124}$.

The differences between Catalan law and the civil law codified in 1889 regarding this matter could not be greater. Article 764 of the civil law affirms: 'The will is valid even if it does not contain the institution of the heir, or if it does not include the entire property, or even if the named does not accept the inheritance or is incapable of inheriting, adding - to make testate succession compatible with intestate succession - 'In these cases the testamentary dispositions made in accordance with the laws will be obeyed, and the residuary legacy will pass to the legitimate heirs'.

As corollary of the criteria previously alluded to regarding historical Catalan successions law which, we emphasise, concurred to uphold the institution of the family over time as a unit that perpetuates beyond the death of individual fathers as head of the family, we can highlight two essential principles: the principle of semel heres, semper heres and that of indivisibility in the acceptance or rejection of inheritances ${ }^{125}$. These principles give the patrimonial order in the family stability by means of a steady successions system and, from testamentary freedom and through the principle of the universality of succession, they facilitate the safeguarding of family structures over time.

\section{The dignity of the widowed mother}

This concept was made absolutely clear in the testamentary clause that custom had made law in Catalan notarial practice:

I bequeath to my wife, Our Mistress, great and powerful, the usufruct of my entire estate and assets for the rest of her natural life or until she remarries. With the product of this she has the duty of keeping the heir, his spouse and their family in the family home, as well as all of my other offspring until, in the case of the boys they have a profession or a degree, and in the case of the girls until they marry, supplying them with food and clothing, in sickness and in health, while they in turn work in whatever way they can to be of use to the hou-

\footnotetext{
122 J. de MORAGAS DE TAVERN: L'Hereu, Barcelona, 1888.

123 Joan MARTí I MIRALLES: Principis del Dret Successori aplicats a fórmules d'usdefruit vidual i d'herència vitalícia, Barcelona, 1925, p. 21.

${ }^{124}$ MARTÍ I MIRALLES: Principis del Dret Successori, p. 22.

${ }^{125}$ The first of these principles is a mere consequence of the principle of incompatibility of testate and intestate succession, which is the second direct consequence of the principle of universality of succession. MARTí I MIRALLES: Principis del Dret Successori, pp. 37-46.
} 
sehold ${ }^{126}$.

From this clause we can see that it was usual to consider the widow to be the successor to the position of authority that her husband had occupied ('Our Mistress, great and powerful'), to the parental rights that he had exercised (specifically as guardian and caregiver of the offspring), and to the position of general administrator of the family patrimony ('usufruct of my entire estate and assets'.) In the same way, she also took on all of the duties that befell the father of the family [the duty of keeping (...) the heir, his spouse and their family in the family home, as well as all of my other offspring (...)'].

And so, because it was custom, we can talk about the dignity of the widowed mother as a principle of Catalan law, but always remembering that this notarial practice depended on the wishes of the deceased at the time the will was made: The wife's subrogation of the husband's position was not a legal obligation but a decision taken freely on the part of the husband and set down in the will.

The justification for this system was that 'the legal conscience of Catalonia has always preferred conventional law born of free will to the inflexible regulations born of the law', which determined, in Juan de Dios Trías's opinion, that 'Catalonia finds itself in the position of asking the public powers (...) that through their tribunals they do not obstruct nor distort the apparatus and organism of our institutions. Neither do they restrict the freedom of the head of the family by means of impertinent guardianship, because the father and husband (who are not all unnaturally detached as the Code supposes and takes for granted) who is at home with his wife and offspring, usually knows better than the legislator who blindly legislates and regulates $^{127}$.

So even though the law only guaranteed Catalan wives the quarta marital (a quarter of her husband's assets, which alone was not normally above poverty level) and the transitory rights that came from the tenuta (the right of the widow to possess all of her husband's property, while this is not reciprocal) and the institution of the any del plor (the widow's right to continue living in the shared home and be fed during the year following her husband's death), in practice it preferred the traditional Catalan legal system which guaranteed the wife full freedom to manage and administer her parafernales (the separate property of a married woman).

The Catalan legal tradition does not recognise the marital financial system of gananciales (all property that is acquired or increased, except by gift or inheritance, during the marriage, which belongs to both spouses in equal shares); it does not concede this patrimonial guarantee to wives beyond the marriage, preferring a conventional system made manifest in marriage agreements or in testamentary clauses such as those described above, thus allowing the father of the family from his position of supreme authority to treat each case with the fairness required.

In the middle of the nineteenth century Catalan jurists in general considered that their civil law conferred upon women a very dignified legal position and accusations to the contrary were met

\footnotetext{
${ }^{126}$ The clause in FALGUERA: Conferencias etc., p. 35.

${ }^{127}$ TRÍAS: Conferencias de Derecho civil catalán, p. 89. The author describes as 'not very uplifting, the spectacle that the Castilian family puts on when the head of the family dies'. And he relates, in his opinion, the circumstance brought about by the Civil Code: 'As if the death of the head was the end of the family; and as if this sacred link was a business deal, a stock take is made (...) the children and the mother dividing the marital gains and arguing over the assets of the deceased, ibid.
} 
with extreme irritation:

Listening to this anybody would think that here in Catalonia we live in harems, or that our women are held in straitjackets, when the truth is that they enjoy a legal position they could never expect to aspire to in Castile ${ }^{128}$.

However, it is undeniable that Catalan jurists were much less critical of the legal position of married women than they were of other related situations such as that of the son who had reached the age of majority but was single and not emancipated and for whom Falguera himself sought a better legal position. These suggested adaptations to traditional Roman law as it applied in Catalonia did not specifically attempt to improve the situation of women within the family system: The jurists of the Catalan Legal School said nothing, for example, about giving wives the parental rights which were denied to them by Roman law.

\section{4. and 5. Personal responsibility and free activity as the condition of all human action in relation to assets.}

As Durán Bas reminds us, 'regarding the ability to transmit our rights over things, whether it be the right of possession or any of the other rights that the law recognises, we also find in Roman law the rules that apply in Catalonia ${ }^{129}$.

For jurists of the Catalan Legal School any change that contemporary law attempted to impose upon the order of total freedom to dispose of property constituted an assault on tradition and Catalan law which, because it was based on Roman law, was bestowed with transcendent authority.

\footnotetext{
${ }^{128}$ TRÍAS: Conferencias de Derecho civil catalán, p. 88.

${ }^{129}$ DURÁN I BAS: Memoria, p. 111.

${ }^{130}$ FALGUERA: Conferencias de Derecho Catalán, p. 84.
}

The debate on the institution of the emphyteutic annuity, which the codification process sought to abolish, is a case in point. It was argued that legally and economically ensuring a reunification of the institution of property in order to leave behind the decomposition of property characteristic of the Old Regime (divided into direct property, useful property etc) was what was needed

About this contemporary principle the eminent exponent of the legal criteria of the CataIan Legal School Félix María de Falguera said: 'The State must procure nothing and facilitate everything (...). Let the owner join, separate, cut or break up or enlarge his property'. He added:

The State must procure nothing and facilitate everything, because the crudest countryman can show the best way to legislate with respect to his own situation than the most arrogant men of the State. It seems that (the State) considers all men to be like children when they want to be like their guardian, making laws in a precise and inalterable manner about how they must run their businesses and speculations about real estate property. (...) Legislators should stop busying themselves so enthusiastically with private interests because the individual knows what is best for him, not those who wish to put themselves in the position of their guardian $(. . .)^{130}$

This principle of freedom and full responsibility as criteria of the relationship between the owner and his estate was related to the fact that property and its administration were considered to be linked to the authoritarian figure 
of the father, the institution from which this freedom was made compatible with the organic order of a traditional society such as was being defended in Catalonia by the jurists of the CataIan Legal School.

Right from the start Catalan jurists' attitude to the institution of the annuities took on a defining characteristic, at least in its most authentically legal aspect: concern with preserving (the annuities) framed in a liberal context, divested of any political or legal aspect and regulated exclusively by the principle of freedom of contract.

This legal adaptation of the institution of the emphyteutic annuity to the new political and economic order was effected at the University of Cervera, and from there it fuelled all of the arguments that years later the Catalan Legal School would present against the project of the Codification of Civil Law in Spain. The most in- fluential professors of the University of Cervera in this respect were Jaime Tos Urgellés ${ }^{131}$ and Ramón Lázaro de Dou Bassols ${ }^{132}$.

For many what is clear is the fact that in CataIonia the consequence of the strength of the social class of landowners was their enormous interest in maintaining the institution of the emphyteutic annuity in all of its different forms across the territory. Things, however, would not that simple.

To begin with, the general thinking of the Projects of the Civil Code collided headlong with an enlightened secular Catalan literature ${ }^{133}$ that had been explaining that the agrarian progress of the region had come about thanks to the virtues of the emphyteutic contract ${ }^{134}$.

The strength of the institution of the emphyteutic annuity even led to the possibility of expropriating the beneficial ownership of areas of uncultivated land to concede them to annuity. Tos

131 Jaime TOS I URGELLÉS: Tratado de Cabrevación, según el Derecho y estilo del Principado de Cataluña. Sus utilidades y efectos, del modo de principiar, y seguir las causas de cabrevación. De los Privilegios y pretensiones del señor directo, o mediano, y de las escepciones que competen al reo o enfiteota. Adicionado con la Disertación de la firma por razón de señorío y Derecho de pre- lación, tanteo o fadiga y adición al tratado de cabrevación. These two works form a single volume with a general analytical index. In these, for the first time, there appears the doctrine that Manuel Durán i Bas himself would use in relation to perpetual emphyteusis and the establishment of the first vines. I work with the edition that was published in Barcelona in 1826

${ }^{132}$ In his work La riqueza de las Naciones nuevamente explicada con la doctrina de su mis- mo investigador, published in Cervera in 1824, and from the commentary of a fundamental work to understand economic liberalism, he dedicates several pages (pp. 185-195) to laying out the basis of the reasons why adapting the institution of the emphyteutic annuity to the new contemporary order was very much in their interests. In the same vein, although rather going over the same ground, his Proyecto sobre laudemios, Cervera, 1824. And again in his work Pronta y fácil ejecución del Proyecto sobre laudemios fundada principalmente en una autoridad del Dr. Adán Smith, Cervera, 1831.

${ }^{133} \mathrm{Cf}$. References in Pierre VILAR: Catalunya dins I'Espanya moderna, III, pp. 554 et seq; Ernest LLUCH: El pensament econòmic a Catalunya (1760-1840). Els orígens ideològics del proteccionisme i la presa de consciència de la burguesia catalana, Barcelona, 1973, pp. 23-24, 47, 57 et seq, 108, 207.

Outside Catalonia there were also many who revindicated the enphyteusis. In this regard, Pedro RODRÍGUEZ DE CAMPOMANES: 'the sharing out of uncultivated land to perpetual emphyteusis would double the size of the neighbourhood, and would give their own a good income: landowners across the kingdom do this, and in the Royal Patrimony in Catalonia, Valencia and other parts (...) It is necessary to end up taking part in this operation to put the kingdom in its natural and potential production', Apéndice a la Educación Popular, Madrid, 1775-1777, note 332, speech 8.0, part 4.a.

${ }^{134}$ This starting point was common to any legal study of the institution that existed in Catalonia before the XIX century. Cf. TOS I URGELLÉS: Tratado de la Cabrevación, p. I: 'If we see our Principality in such a prosperous state, the population increased, and trade. If we see most of the land that can be used given over to cultivation, then who would doubt that this was due largely to the frequency and use of emphyteutic contracts, which are called establishments in Catalonia?' 
Urgellés said:

I do not ignore the fact that you cannot force the owner to part with his property, not even if it is for a fair price. But this disposition stops when, for the benefit of public use, the Prince can dispose of the property of his subjects. For a public building or similar should not a person sell their land? Why couldn't we also do this for the use and promotion of farm work, population, commerce, industry, particularly retaining the legal ownership, its product and the recognition, as a thing of the emphyteusis ${ }^{135}$.

The Informe of the Council of Commerce of Barcelona and a piece written by Guillermo Oliver Salvá ${ }^{136}$ of 1816 is often cited as an example of this literature. Its thinking was that the emphyteusis was the basis of agrarian wealth of Catalonia, but at the same time it pointing out the need for certain reforms to be made to this institution: basically, the reduction of excessive laudemios (the dues paid to the lord of the manor on all transfers of landed property within the manor) and the elimination of the fadiga (the right of first refusal to the lord of the manor in enfiteusis).

Dou Bassols was another important author of a legal tradition which in Catalonia aimed to maintain the institution of the annuities with its own criteria. With regards to the laudemios, Dou Bassol's main point was that: 'everything, including the laudemio, should be to the satisfaction of the interested parties, free and not subject to any taxes $^{\prime 137}$. It was precisely because of this revindication of the contractual nature of the institution that they also defended maintaining the pre-existing emphyteusis exactly as they were, regulated 'by the previously established law in the respective province.'

In the new times, however, the liberals suggested changes to this: ' they say that the State must procure the unity of the land', criteria that were categorically denounced by the most prominent members of the Catalan Legal School. Falguera responded unhesitatingly to this categorical presumed obligation of modernity: 'The State must procure nothing and facilitate everything (...). Let the owner join, separate, cut or break up or enlarge his property ${ }^{\prime 138}$.

Why are more contracts entered into in CataIonia, especially regarding property law peculiar to possession? Because there property is divided into a greater number of elements and so acquiring it is easier. One with insufficient wealth to buy the whole, called freehold, can acquire part of it, called annuity or right to redeem, or something else; and another day, on the strength of more savings, he acquires another part, and gradually he becomes a property owner (...). So, if you want to know the secret as to why there is more trade in real estate and more property laws in Catalonia, then here it is. It is because there all of the possible decompositions of property are allowed, and a saleable element is made of each, and all of these entities are thrown onto the market. This demons-

\footnotetext{
${ }^{135}$ TOS I URGELLÉS: Tratado de la Cabrevación, p. VII.

${ }^{136}$ The Informe can be found in the Library of Catalonia. Archive of the Royal Committee of Commerce of Barcelona, Book 101. Copyier of Letters and Representations and Trades. In this regard, LLUCH: El pensament econòmic a Catalunya, pp. 247 et seq.; CODERCH: La Compilación y su historia, pp. 32 et seq.

${ }^{137}$ DOU I BASSOLS: Conciliación Económica y Legal de pareceres opuestos en cuanto a Laudemios y Derechos Enfitéuticos, 1829, núm. 65.

${ }^{138}$ FALGUERA: Conferencias de Derecho Catalán, p. 84
} 
trates that its suppression is non-commercialli39.

It was not a case, therefore, of creating anti-modern arguments. On the contrary, it was a case of inflating traditions with liberalism, so that the new times did not signify a break with tradition, but a strengthening of the traditional.

Aside from Guerilla's previously mentioned affirmations, he also put forward another important argument to defend the need to be able to divide: 'because in Catalonia there is the custom of naming a sole heir, which brings about the accumulation and stagnation of property,' the decomposition of the land into a multitude of property rights to counterbalance this tendency could also be a possibility.

(...) perpetual emphyteusis was allowed for those who possessed connected property, without the need for information or for legal decree, so as not to have to make an initial downpayment See here how sole heirship does not impede expropriations nor does it facilitate accumulation ${ }^{140}$.

First and foremost, it was a question of mindsets: 'the emphyteusis, called establishment in Catalonia, is a very usual contract, because it is not considered dishonourable for large landowners, whereas the sale of property is ${ }^{\prime 141}$.

The heir, the son who substitutes his father as head of the family can not honourably sell; he must not alienate pieces of patrimonial history that are bound to his ancestors and that are part of the process of constructing a family home that shelters all of its members and to which all of its members respond. The heir can not sell but he can constitute annuities on his properties, which does

\footnotetext{
${ }^{139}$ FALGUERA: Conferencias de Derecho Catalán, p. 89.

140 FALGUERA: Conferencias de Derecho Catalán, p. 94.

141 /bid.
}

not mean getting rid of them - as they continue to be family property - but means that he has a way of making them profitable so that he has the money to fulfil his family responsibilities. Establishing annuities meant, for example, that he could provide a dowry for a sister, or he could cover the forced rights of a brother who needed to make his way in the world; and this whilst keeping the family patrimony intact, without breaking it up or alienating it.

And so the emphyteutic annuity was a key institution for Catalan legal traditionalism of the nineteenth century because it adapted perfectly to family law and to Catalan successions law which, as we discussed previously in relation to the second key principle of Catalan law, was one of the structural elements of traditional Catalan society.

The emphyteutic annuity was the procedure through which the Catalan successions custom of the heir did not result in the union and accumulation of real estate but it served as a channel to adapt that society to modernity and liberalism.

Viewed this way, the legal movement in favour of generalised exemption from the annuities and the prohibition of the emphyteutic annuity actually meant blocking the way to modernising traditional Catalan society. It meant stopping a way of being and understanding the world from entering economic and legal liberalism. This way of being and understanding the world was not the only typically Catalan one in the middle of the nineteenth century, but it did represent a large percentage of the peoples of that territory.

The importance of the matter lay in the fact that the principle of the redeemability of the annuities constituted an assault on the Catalan concept of 
family property: that property that the father owned, that property that came imbued with a set of moral responsibilities that gave it a 'collective character which cannot be denied'142.

Furthermore, this family property law was not regulated by any constitution or explicit regulation: as Abadal said it was 'a law that is lived, from the law that is breathed by those who live their lives in an environment that abounds with the Catalan idea of the law, without doubts, without contradictions, without disputes'143; which converted this legal situation into a highly delicate system, partly ethereal and extremely delicate in that it was not explicitly and clearly manifested in any legal system that was specifically defensible. The very decided attitude of the group of jurists that represented the Catalan Legal School is, therefore, understandable.

\section{The law 'limited to the require- ments of order and peace in social relations'.}

There are various implications of an organic concept of Catalan law, but there is one in particular: the establishment of a direct and exclusive dependency between the law and social structures that operate outside the influence of public powers. The law is understood to be not so much a product of political and administrative institutions as a reflection of the social organism.

This organic concept of Catalan law, along with its traditionalism, creates constant problems when trying to integrate the Catalan legal tradition into the contemporary constitutional legal system that started to be constructed in Spain at the beginning of the nineteenth century.

The Catalan legal tradition found 'modern law' contradictory in that it gave citizens enormous freedom 'in the political order and in other systems that have nothing to do directly with the interests of the citizen', whilst at the same time it restricted civil liberty. The law of suffrage is a clear example of this contradiction: the only requirement for the right to vote was to have reached the age of majority, whereas traditional civil liberties such as testamentary freedom and the parental right of the father were being limited by the Civil Code and various special laws ${ }^{144}$.

The fundamental principle was that laws had to come not so much from the law as from agreement, from accord, from pacts freely made by social organisms. And the main point of reference of these social organisms was the family

\footnotetext{
${ }^{142}$ ABADAL: Característica de la Propietat Catalana. Conferencia feta en I'Academia de Ju-risprudencia y Llegislació de BarceIona el día 21 de mars de 1898, Vich, 1900, p. 11.

${ }^{143} \mathrm{Ibid}$.

${ }^{144}$ TRÍAS: Conferencias de Derecho civil catalán, p. 42.
} 